\title{
Kinerja Perawat RSUD Hasanuddin Damrah Manna
}

\author{
Agung $^{1}$, Ratnawili ${ }^{2}$ \\ 1,2Universitas Muhammadiyah Bengkulu \\ ratnawili@umb.ac.id
}

\begin{abstract}
ABSTRAK
Penelitian ini bertujuan untuk mengetahui pengaruh locus of control, self efficacy dan self esteem terhadap kinerja perawat pada RSUD Hasanuddin Damrah Manna. Sampel dalam penelitian ini sebanyak 162 orang perawat yang bekerja pada RSUD Hasanuddin Damrah Manna dan telah menjadi PNS, karena semua populasi dalam penelitian ini dijadikan sampel, maka metode pengambilan sampel dengan cara sensus. Teknik pengumpulan data menggunakan kuesioner. Teknik analisis yang digunakan adalah regresi linier berganda, koefesien determinasi dan pengujian hipotesis.

Hasil penelitian menunjukkan bahwa dari perhitungan persamaan regresi linier berganda dapat diketahui bahwa X1 (Locus of control), X2 (Self Efficacy) dan X3 (Self Esteem) mempunyai pengaruh terhadap Kinerja (Y), dengan hasil uji regresi $: \mathrm{Y}=10,422+0,172 \mathrm{X} 1+0,257 \mathrm{X} 2+0,335 \mathrm{X} 3$. Nilai koefesien determinasi sebesar dari $R$ square yaitu sebesar sebesar 0324. Hal ini berarti bahwa X1 (Locus of control), X2 (Self Efficacy) dan X3 (Self Esteem) berpengaruh terhadap Kinerja (Y) sebesar 32,4 \% sedangkan sisanya 67,6\% dipengaruhi oleh faktor-faktor penyebab lainnya yang tidak diteliti dalam penelitian ini. Berdasarkan hasil pengujian dengan uji t, hipotesis yang dibuat membuktikan ada pengaruh. Variabel X1 (Locus of control), X2 (Self Efficacy) dan X3 (Self Esteem) menunjukkan nilai $t_{\text {hitung }}$ lebih besar dari $t_{\text {tabel }}$ dan nilai signifikansi lebih kecil dari 0,05. Artinya X1 (Locus of control), X2 (Self Efficacy) dan X3 (Self Esteem), memiliki pengaruh yang positif dan signifikan secara partial terhadap kinerja (Y) perawat pada RSUD Hasanuddin Damrah Manna. Berdasarkan hasil pengujian hipotesis dengan uji $\mathrm{F}$, nilai $F_{\text {hitung }}>F_{\text {tabel }}(25,221>3,05)$ dan nilai signifikan sebesar $0,000<0,05$ artinya terdapat pengaruh secara simultan dari X1 (Locus of control), X2 (Self Efficacy) dan X3 (Self Esteem), terhadap kinerja (Y) perawat pada RSUD Hasanuddin Damrah Manna
\end{abstract}

Kata Kunci : Kinerja Perawat, Locus of control, Self Efficacy, Self Esteem 


\section{BAB I}

\section{PENDAHULUAN}

\subsection{Latar Belakang}

Sumber daya manusia merupakan salah satu aset terpenting bagi perusahaan. Peranan sumber daya manusia bagi perusahaan tidak hanya dilihat dari hasil produktivitas kerja tetapi juga dilihat dari kualitas kerja yang dihasilkan. Oleh karenanya kinerja karyawan merupakan hal yang patut mendapat perhatian penting dari pihak perusahaan. Sumber daya manusia yang ada juga perlu dikelola dan dibina agar mereka merasa puas dalam melaksanakan pekerjaannya sehingga mampu berkontribusi untuk kinerja dan kemajuan perusahaan tersebut.

Keberhasilan suatu organisasi dipengaruhi oleh kinerja (job performance) dari karyawannya. Kinerja atau prestasi kerja adalah hasil kerja yang dicapai oleh seseorang dalam melakukan tugas sesuai dengan tanggung jawab yang diberikan kepadanya. Faktor yang mempengaruhi kinerja adalah kemampuan (ability) dan faktor motivasi. Setiap organisasi maupun perusahaan akan berusaha untuk meningkatkan kinerja pegawai untuk mencapai tujuan organisasi yang telah ditetapkan (Mangkunegara, 2008, Onsardi, 2020).

Kinerja berhubungan erat dengan sikap dari karyawan terhadap pekerjaannya sendiri, situasi kerja, kerja sama antar pimpinan dan sesama karyawan. Menurut Siagian (2009) mendefinisikan kinerja sebagai suatu keseluruhan kemampuan seseorang untuk bekerja sedemikian rupa sehingga mencapai tujuan kerja secara optimal dan berbagai sasaran yang telah diciptakan 
dengan pengorbanan yang secara rasio lebih kecil dibandingkan dengan hasil yang dicapai.

Locus of control merupakan salah satu faktor penentu kinerja individu selain variabel kemampuan pribadi lainnya. Organisasi pasti memiliki komitmen organisasional pada dasarnya berkaitan dengan kedekatan para karyawan terhadap organisasi. Dengan adanya kebutuhan karyawan yang dapat terpenuhi melalui pekerjaan yang dilakukannya akan menimbulkan suatu komitmen dari pihak karyawan yang akan memberikan pengaruh besar terhadap kelangsungan hidup organisasi. Organisasi membutuhkan karyawan yang bersedia untuk bekerja keras demi kepentingan organisasi dan bersedia terlibat secara penuh dalam upaya mencapai tujuan dan kelangsungan hidup organisasi.

Locus of control yang baik akan memberikan dampak positif bagi karyawan dalam meningkatkan kinerja suatu karyawan . Hal ini merupakan salah satu cara agar karyawan tidak mengalami gangguan dalam menyelesaikan pekerjaannya, karena setiap individu merasa dapat mengontrol dirinya sendiri maka mereka akan lebih mampu mengendalikan akibat dan yang terjadi dalam lingkungan sehingga akan lebih merasa puas dengan pencapaian yang sudah dilakukan, karena itu locus of control sangat mempengaruhi kinerja karyawan .

Manusia mempunyai kehendak, kemauan dan cita-cita. Kinerja yang diaktualisasi oleh karyawan juga didukung oleh beberapa faktor. Dalam perilaku organisasi yang merupakan studi mengenai apa yang orang-orang lakukan dalam sebuah organisasi dan bagaimana perilaku mereka mempengaruhi kinerja organisasi. Dimana perilaku organisasi mencakup topik-topik inti : motivasi, 
perilaku dan kekuasaan pemimpin, komunikasi interpersonal, struktur dan proses kelompok, pengembangan dan persepsi sikap, proses perubahan, konflik dan negosiasi, rancangan kerja. Yang menjadi pilihan faktor yang mempengaruhi kinerja karyawan untuk dijadikan penelitian adalah topik motivasi dengan teori self efficacy- nya dan topik pengembangan dan persepsi sikap yang diwakili oleh self esteem.

Menurut Alwisol (2014), self-efficacy adalah persepsi mengenai seberapa bagus diri dapat berfungsi dalam situasi tertentu. Self efficacy adalah sebuah keyakinan tentang probabilitas bahwa seseorang dapat melaksanakan dengan sukses beberapa tindakan atau masa depan dan mencapai beberapa hasil. Efikasi diri mencerminkan suatu keyakinan individu sesaat disaat kemampuan mereka melaksanakan suatu tugas spesifik pada suatu tingkatan kinerja yang spesifik. Self efficacy akan mendorong seseorang lebih bersemangat mencapai hasil optimal dalam kinerjanya, hal ini dibuktikan dengan penelitian Stevani (2017).

Selain self efficancy, self esteem juga dapat mempengarhi kinerja. Gardner et. al (2013) mendefinisikan self esteem sebagai suatu keyakinan nilai diri sendiri berdasarkan evaluasi diri secara keseluruhan. Semakin tinggi self esteem yang dimiliki oleh seorang karyawan akan meningkatkan kinerja individu karena adanya tingkat harga diri yang membuat mereka merasa dihargai sehingga karyawan berusaha bekerja dengan lebih baik dan kinerja semakin meningkat. Sebaliknya, jika harga diri (self esteem) yang dimiliki seorang karyawan rendah maka kinerjanya akan semakin menurun. 
Seorang perawat akan memiliki rasa optimisme yang tinggi jika mempunyai self efficacy dan self esteem yang tinggi. Perawat mempunyai kepercayaan diri yang tinggi berkaitan dengan kemampuannya dalam bekerja dibandingkan dengan orang yang memiliki self efficacy rendah, selain itu self efficacy dan self esteem yang tinggi juga menurunkan rasa takut akan kegagalan karena perawat lebih berani mengambil resiko sehingga pada saat menolong pasien mereka akan berpikir cepat dan dapat mengatasi pasien tersebut secara efektif karena tidak ragu-ragu dalam bertindak. Tingginya self efficacy dan self esteem menurunkan rasa takut akan kegagalan, meningkatkan aspirasi, meningkatkan cara penyelesaian masalah, dan kemampuan berfikir analitis.

Orang yang memiliki self efficacy dan self esteem yang tinggi akan mempunyai semangat yang lebih tinggi di dalam menjalankan suatu tugas tertentu dibandingkan dengan orang yang memiliki self efficacy dan self esteem yang rendah. Sehingga seorang perawat yang memiliki self efficacy dan self esteem yang tinggi akan mengembangkan sikap-sikap positif seperti percaya diri dan berkomitmen tinggi, dengan demikian ia pun mampu menjalankan peran dan fungsinya dengan baik.

RSUD Hasanuddin Damrah Manna adalah rumah sakit pemerintah yang ada di kota Manna. Dalam memberikan pelayanan terhadap pasien, perawat dituntut memberikan perawatan yang cepat, tepat dan profesional. Pada saat ini RSUD Hasanuddin Manna memiliki sebanyak 670 orang pegawai dan sebanyak 233 orang pegawai berprofesi sebagai perawat. Berdasarkan hasil pra penelitian dengan cara melakukan wawancara dengan perawat senior yang bekerja di RSUD Hasanuddin 
Damrah Manna yaitu Ibu Destia dan Ibu Evi pada tanggal 19 Desember 2019 jam 14.00 WIB ditemukan bahwa tingginya tanggung jawab seorang perawat dalam bekerja. Perawat harus menghadapi desakan, kepanikan, keluhan berlebihan serta ketidaksabaran pasien dan keluarganya. Meskipun para perawat jaga telah berusaha maksimal untuk memberikan pertolongan pada pasien sesuai dengan standar pelayanan yang di diinstruksikan dokter. Selain menjalankan instruksi dokter, beberapa tugas perawat yang umum dilakukan yaitu melaksanakan observasi gejala dan respon pasien yang berhubungan dengan penyakit dan penyebabnya, memantau pasien, menyusun dan memperbaiki rencana keperawatan secara kontinyu berdasarkan pada kondisi dan kemampuan pasien, mencatat dan melaporkan keadaan pasien, melaksanakan prosedur dan teknik keperawatan, memberikan pengarahan dan penyuluhan untuk meningkatkan kesehatan fisik dan mental pasien. Karena banyaknya tugas dan tanggungjawab perawat dapat mengakibatkan perawat lepas control atau lepas kendali sehingga menyebabkan perawat kurang sopan pada saat keluarga pasien menanyakan keadaan pasien. Tekanan kerja dan rutinitas kerja perawat dalam bekerja, memerlukan dukungan mental yang mampu mengendalikan dan mengelola emosi secara positif, serta mampu mengontrol diri sendiri, mampu mengenali emosi orang lain, dan mampu membina hubungan dengan orang lain, sehingga akan terjalin hubungan saling percaya dan saling membantu antara perawat dengan pasien, perawat dengan keluarga, perawat dengan dokter, perawat dengan tim kesehatan yang lainnya.

Berdasaran hasil pra penelitian tersebut diduga ada beberapa faktor yang dapat mempengaruhi kinerja perawat dalam bekerja diantaranya locus of control, 
self efficacy dan self esteem. Dugaan tersebut berdasarkan penjelasan yang disampaikan oleh Ibu Destia dan Ibu Elvi pada saat dilakukan observasi pra penelitian. Beberapa fenomena yang ditemui menunjukkan bahwa perawat yang mempunyai kinerja kurang baik adalah perawat kurang percaya diri, merasa tidak mampu menangani pasien dengan baik, melakukan pekerjaan hanya berdasarkan intruksi dokter, menjadikan profesinya sebagai beban, mudah stres ketika menghadapi masalah dalam pekerjaannya, dan kurang disiplin. Hal ini terlihat dari kurangnya keyakinan dari perawat untuk melakukan perawatan terhadap pasien karena mereka takut salah dan merasa ragu-ragu.

Dari uraian di atas sehingga judul yang diangkat dalam penelitian ini adalah "Pengaruh Locus of Control, Self Efficacy dan Self Esteem terhadap kinerja perawat pada RSUD Hasanuddin Damrah Manna”.

\subsection{Identifikasi Masalah}

Adapun penyebab terjadinya masalah dalam penelitian ini adalah masih kurangnya percaya diri dari para perawat dalam melakukan perawatan terhadap pasien karena mereka tidak memiliki keyakinan atas kemampuan yang ada pada dirinya. Hal lain dapat dilihat juga masih kurangnya pengontrolan diri dari perawat pada saat melayani pasien maupun keluarga pasien.

\subsection{Rumusan Masalah}

Berdasarkan latar belakang yang telah diuraikan di atas, maka rumusan masalah penelitian ini adalah : 
1. Bagaimanakah pengaruh locus of control terhadap kinerja perawat pada RSUD Hasanuddin Damrah Manna?

2. Bagaimanakah pengaruh self efficacy terhadap kinerja perawat pada RSUD Hasanuddin Damrah Manna ?

3. Bagaimanakah pengaruh self esteem terhadap kinerja perawat pada RSUD Hasanuddin Damrah Manna ?

4. Bagaimanakah pengaruh locus of control, self efficacy dan self esteem terhadap kinerja perawat pada RSUD Hasanuddin Damrah Manna ?

\subsection{Batasan Masalah}

Adapun batasan masalah dalam penelitian ini adalah untuk mengetahui pengaruh locus of control, self efficacy dan self esteem terhadap kinerja perawat pada RSUD Hasanuddin Damrah Manna .

\subsection{Tujuan Penelitian}

\subsubsection{Tujuan Umum}

Adapun tujuan dalam penelitian ini adalah untuk mengetahui kinerja perawat dari segi locus of control, self efficacy, self esteem

\subsubsection{Tujuan Khusus}

Adapun tujuan dalam penelitian ini adalah:

1. Untuk mengetahui pengaruh locus of control terhadap kinerja perawat pada RSUD Hasanuddin Damrah Manna 
2. Untuk mengetahui pengaruh self efficacy terhadap kinerja perawat pada RSUD Hasanuddin Damrah Manna

3. Untuk mengetahui pengaruh self esteem terhadap kinerja perawat pada RSUD Hasanuddin Damrah Manna

4. Untuk mengetahui pengaruh locus of control, self efficacy dan self esteem terhadap kinerja perawat pada RSUD Hasanuddin Damrah Manna

\subsection{Manfaat Penelitian}

1. Manfaat Teoritis

Hasil penelitian ini diharapkan dapat memberikan dukungan terhadap teori pengaruh atas dengan locus of control, self efficacy dan self esteem terhadap kinerja.

2. Manfaat Praktis

1. RSUD Hasanuddin Damrah Manna, adalah sebagai bahan masukan dan pertimbangan dalam pembinaan sumber daya manusianya yang berkenaan dengan locus of control, self efficacy dan self esteem dalam meningkatkan kinerja perawat

2. Bagi Peneliti lain, dapat menambah pengetahuan sebagai bekal dalam menerapkan ilmu yang telah diperoleh dibangku kuliah dalam dunia kerja yang sesunguhnya. 


\section{BAB II}

\section{KAJIAN PUSTAKA}

\subsection{Landasan Teori}

\subsubsection{Kinerja}

Menurut Mangkunegara (2008), kinerja merupakan hasil kerja secara kualitas dan kuantitas yang dicapai oleh seseorang dalam melaksanakan fungsinya sesuai dengan tanggungjawab yang diberikan kepadanya. Tidak jauh berbeda, penulis lain mendefinisikan kinerja sebagai suatu keseluruhan kemampuan seseorang untuk bekerja sedemikian rupa sehingga mencapai tujuan kerja secara optimal dan berbagai sasaran yang telah diciptakan dengan pengorbanan yang secara rasio lebih kecil dibandingkan dengan hasil yang dicapai, (Siagian 2009, Onsardi, 2018).

Prawirosentono (2013) lebih cenderung menggunakan kata performance dalam menyebut kata kinerja. Menurutnya performance atau kinerja adalah hasil yang dapat dicapai oleh seseorang atau sekelompok orang dalam suatu organisasi, sesuai dengan tanggungjawab masing-masing dalam rangka mencapai tujuan organisasi bersangkutan secara legal, tidak melanggar hukum dan sesuai dengan moral maupun etika.

Berbagai pendapat diatas dapat menggambarkan bahwa kinerja pegawai dan kinerja organisasi memiliki keterkaitan yang sangat erat, tercapainya tujuan organisasi tidak bisa dilepaskan dari sumber daya yang dimiliki oleh organisasi yang digerakan atau dijalankan pegawai yang berperan aktif sebagai pelaku dalam upaya mencapai tujuan organisasi.Jadi dapat disimpulkan bahwa kinerja pegawai 
adalah penilaian hasil kerja seseorang dalam suatu organisasi sesuai dengan tugas dan tanggungjawabnya dalam rangka mencapai tujuan organisasi.

Menurut Sutrisno (2010) beberapa fakor yang mempengaruhi kinerja yaitu:

a) Keterampilan merencanakan, meliputi : menilai dan menetapkan priorias dari bidang hasil, merancang rencana jangka panjang dan pendek yang realistis, merumuskan jadwal yang mungkin, mengantisipasi masalah-masalah yang mungkin dan hambatan-hambatan kearah pencapaian hasil yang dituntut

b) Keterampilan mengorganisasi, meliputi : mengelompokkan kegiatan demi penggunaan optimal atas sumber-sumber personel dalam rangka mencapai tujuan, secara jelas mendefinisikan tanggung jawab dan batas mewenang bawahan dan meminimalkan kebingungan dan ketidakefisienan dalam operasi kerja

c) Keterampilan mengarahkan, meliputi : kemampuan untuk memandu dan menekankan proses motivitasi, keomunikasi dan kepemimpinan.

d) Keterampilan mengendali, meliputi : menetapkan prosedur yang tepat untuk terinformasi tentang kemajuan kerja bawhaan, mengindentifikasi simpangan dalam kemanjuan tujuan kerja dan menyesuaikan diri dala kerja untuk memastikan bahwa tujuan yang ditetapkan telah dicapai

e) Menganalisis masalah meliputi : menetapkan dana yang berhubungan dengan permasalahan, membedakan fakta-fakta yang berarti dari yang kurang berarti, menetapkan hubungan timbal balik dan mencapai pemecahan yang kelihatannya praktis. 
Penilaian kinerja dikenal dengan istilah "performance rating" atau "peformance apprasial". Menurut Munandar penilaian kinerja adalah proses penilaian ciri-ciri kepribadian, perilaku kerja, dan hasil kerja seseorang tenaga kerja atau karyawan (pekerja dan manajer), yang dianggap penunjang untuk kerjanya, yang digunakan sebagai bahan pertimbangan untuk pengambilan keputusan tentang tindakan-tindakan terhadap bidang ketenagakerjaan (Anjani, 2019, Asmawi,2017, Onsardi, 2019).

\subsubsection{Indikator Kinerja}

Menurut Mangkunegara (2008), kinerja pegawai dipengaruhi oleh beberapa indikator, yaitu ;

a) Kualitas Pekerjaan (Quality of Work)

Merupakan tingkat baik atau buruknya sesuatu pekerjaan yang diterima bagi seorang pegawai yang dapat dilihat dari segi ketelitian dan kerapihan kerja, keterampilan dan kecakapan.

b) Kuantitas Pekerjaan (Quantity of Work)

Merupakan seberapa besarnya beban kerja atau sejumlah pekerjaan yang harus diselesaikan oleh seorang pegawai. Diukur dari kemampuan secara kuantitatif didalam mencapai target atau hasil kerja atas pekerjaan-pekerjaan baru.

c) Pengetahuan Pekerjaan (Job Knowledge)

Merupakan proses penempatan seorang pegawai yang sesuai dengan background pendidikan atau keahlian dalam suatu pekerjaan. Hal ini ditinjau 
dari kemampuan pegawai dalam memahami hal-hal yang berkaitan dengan tugas yang mereka lakukan.

d) Kerjasama Tim (Teamwork)

Melihat bagaimana seorang pegawai bekerja dengan orang lain dalam menyelesaikan suatu pekerjaan. Kerjasama tidak hanya sebatas secara vertikal ataupun kerjasama antar pegawai, tetapi kerjasama secara horizontal merupakan faktor penting dalam suatu kehidupan organisasi yaitu dimana antar pimpinan organisasi dengan para pegawainya terjalin suatu hubungan yang kondusif dan timbal balik yang saling menguntungkan.

e) Kreatifitas (Creativity)

Merupakan kemampuan seorang pegawai dalam menyelesaikan pekerjaannya dengan cara atau inisiatif sendiri yang dianggap mampu secara efektif dan efisien serta mampu menciptakan perubahan-perubahan baru guna perbaikan dan kemajuan organisasi.

Sedangkan menurut Harbani (2013), indikator yang mempengaruhi kinerja pegawai adalah sebagai berikut :

a) Kemampuan, yaitu kemampuan dalam suatu bidang yang dipengaruhi oleh bakat, intelegensi (kecerdasan) yang mencukupi dan minat.

b) Kemauan, yaitu kesediaan untuk mengeluarkan tingkat upaya yang tinggi untuk tujuan organisasi.

c) Energi, yaitu sumber kekuatan dari dalam diri seseorang. Dengan adanya energi, seseorang mampu merespon dan bereaksi terhadap apapun yang 
dibutuhkan, tanpa berpikir panjang atau perhatian secara sadar sehingga ketajaman mental serta konsentrasi dalam mengelola pekerjaan menjadi lebih tinggi.

d) Teknologi, yaitu penerapan pengetahuan yang ada untuk mepermudah dalam melakukan pekerjaan.

e) Kompensasi, yaitu sesuatu yang diterima oleh pegawai sebagai balas jasa atas kinerja dan bermanfaat baginya, (Onsardi, 2020).

\subsubsection{Locus of Control}

Locus of control (pusat kendali) pertama kali dikemukakan oleh Rotter (2014), seorang ahli teori pembelajaran sosial. Locus of control merupakan salah satu variabel kepribadian (personility), yang didefinisikan sebagai keyakinan individu terhadap mampu tidaknya mengontrol nasib (destiny) sendiri. Robbins dan Judge (2015) mendefinisikan Locus of control sebagai tingkat dimana individu yakin bahwa mereka adalah penentu nasib mereka sendiri. Locus of control dipengaruhi oleh faktor internal dan eksternal. Internal adalah sikap dari individu yang memiliki suatu keyakinan bahwa dirinya merupakan pemegang kendali atas apa-apa pun yang terjadi pada dirinya sendiri, sedangkan eksternal adalah seseoarang memiliki keyakinan bahwa yang terjadi pada diri mereka dikendalikan oleh kekuatan luar seperti keberuntungan dan kesempatan.

Kreitner \& Kinichi (2016), mengatakan bahwa hasil yang dicapai Locus of control internal dianggap berasal dari aktifitas dirinya. Menurut Brownell (2008) mengatakan bahwa locus of control adalah tingkatan dimana seseorang menerima 
tanggung jawab personal terhadap apa yang terjadi pada diri mereka. Sedangkan pada individu locus of control eksternal menganggap bahwa keberhasilan yang dicapai dikontrol dari keadaan sekitarnya. Individu yang memiliki internal locus of control akan berpendapat bahwa mereka akan bergantung hanya pada dirinya sendiri sedangkan individu yang memiliki external locus of control akan merasakan bahwa mereka lebih banyak berharap dan bergantung kepada orang lain dari pada kepada dirinya sendiri dan akan memilih situasi yang akan mengungtungkan dirinya.

Dari pengertian di atas maka dapat dijelaskan bahwa seseorang yang memiliki keyakinan bahwa nasib yang ada dalam kehidupannya ditentukan oleh kemampuan dirinya sendiri, maka seseorang tersebut dikatakan memiliki internal locus of control. Sedangkan seseorang yang memiliki keyakinan bahwa nasib dirinya ditentukan oleh lingkungannya, maka seseorang tersebut dikatakan memiliki external locus of control.

Locus of control adalah sebagai tingkat dimana individu yakin bahwa mereka merupakan penentu nasib mereka sendiri. Internal adalah individu yang yakin bahwa mereka merupakan pemegang kendali atas apapun yang terjadi pada diri mereka, sedangkan eksternal adalah individu yang yakin bahwa apapun yang terjadi pada diri mereka dikendalikan oleh kekuatan luar seperti keberuntungan dan kesempatan yang ada.

\subsubsection{Indikator Locus of Control}


Menurut Robbins dan Judge (2014) indkator dari locus of control terdiri dari:

\section{1) Locus of control internal}

Individu dengan locus of control internal memiliki keyakinan bahwa ia mampu mengendalikan kehidupannya sendiri. Individu bertindak berdasarkan keputusan, kemampuan dan usaha pribadinya sendiri dengan melakukan :
a) Suka bekerja keras
b) Memiliki inisiatif yang tinggi
c) Selalu berusaha untuk menemukan pemecahan masalah
d) Selalu mencoba untuk berfikir seefektif mungkin
e) Selalu mempunyai presepsi bahwa usaha harus dilakukan jika ingin berhasil

2) Locus of control eksternal

Individu dengan locus of control eksternal meyakini bahwa kehidupannya dipengaruhi faktor lain diluar dirinya. Individu percaya bahwa tindakannya dikendalikan oleh nasib, keberuntungan, orang lain atau kekuatan lain diluar dirinya. Dengan ciri-ciri :
a) Kurang memiliki inisiatif
b) Kurang suka berusaha, karena mereka percaya bahwa faktor luarlah yang mengontrol
c) Kurang mencari informasi untuk memecahkan masalah. 
Dalam bahasa yang berbeda, Rotter (2014) mencirikan kedua jenis Locus of control sebagai berikut:

1) Locus of control internal:

a) Segala yang dicapai hasil usaha sendiri

b) Menjadi pimpinan karena hasil usaha sendiri

c) Keberhasian individu karena kerja keras bukan karena keberuntungan

d) Kemampuan individu dapat menentukan kejadian dalam hidup

e) Kehidupan individu ditentukan oleh tindakan sendiri

f) Kegagalan karena perbuatan sendiri

2) Locus of control eksternal:

a) Kegagalan yang dialami individu karena ketidakmujuran.

b) Perencanaan pekerjaan ke depan yang sia-sia

c) Kejadian yang dialami dalam hidup ditentukan oleh orang yang bekerja

d) Kesuksesan individu karena faktor nasib

\subsubsection{Self-Efficacy}

Menurut Bandura (2007), self-efficacy adalah keyakinan individu mengenai kemampuan dirinya dalam melakukan tugas atau tindakan yang diperlukan untuk mencapai hasil tertentu. Self-efficacy merupakan keyakinan dalam kemampuan seseorang untuk mengatur dan mengeksekusi program tindakan yang diperlukan untuk menghasilkan pencapaian yang diberikan, penyebab iniasiasi perilaku, jumlah usaha yang dikeluarkan, kegigihan meskipun mengalami hambatan serta akhir dari kesuksesan. 
Menurut Alwisol (2014), self-efficacy adalah persepsi mengenai seberapa bagus diri dapat berfungsi dalam situasi tertentu. Self-efficacy berhubungan dengan keyakinan bahwa diri memiliki kemampuan tindakan yang diharapkan. Selfefficacy adalah penilaian diri, apakah dapat melakukan tindakan bisa atau tidak bisa mengerjakan sesuai dengan yang dipersyaratkan. Self-efficacy ini berbeda dengan aspirasi (cita-cita), karena cita-cita menggambarkan sesuatu yang ideal yang seharusnya (dapat dicapai), sedang self-efficacy menggambarkan penilaian kemampuan diri dalam bekerja.

Menurut Lauster (2012) mengungkapkan orang yang memiliki Self-efficacy memiliki ciri-ciri tidak mementingkan diri sendiri (toleransi), tidak membutuhkan dorongan orang lain, optimis dan gembira. Berdasarkan pendapat di atas, maka dapat dijelaskan bahwa self-efficacy merupakan suatu keyakinan yang dimiliki oleh seorang pegawai atau guru bahwa dirinya mampu untuk melaksanakan semua tugas dan tanggung jawab yang telah dibebankan kepadanya. Keyakinan dari seorang guru bahwa dirinya mampu memberikan didikan kepada para sisawanya, keyakinan bahwa sebagai guru dirinya mampu memberikan arahan dan bimbingan untuk mendidik siswanya, hal ini merupakan suatu sikap self-efficacy yang ada pada guru tersebut.

Sedangkan menurut Robbins (2014), self-efficacy adalah sikap yang dilandasi atas keyakinan akan kemampuan diri sendiri. Self-efficacy tercermin dalam tindakan-tindakan individu yang tidak terlalu cemas, tidak merasa terbeban untuk melakukan hal-hal yang sesuai keinginan dan tanggung jawab atas 
perbuatannya, sopan dalam berinteraksi dengan orang lain, memiliki dorongan prestasi dan dapat mengenal kelebihan dan kekurangan diri sendiri.

Self-efficacy menentukan bagaimana seseorang merasakan, memikirkan, dan memotivasi dan melakukan perbuatan. Seperti kepercayaan bermacam-macam efek, termasuk keempat proses mayor, yaitu kognitif, motivasi, afeksi dan proses seleksi. Self-efficacy tentu dikaitkan dengan kemampuannya mengatasi permasalahan, dengan perestasi yang pernah dicapainya. Kalau cenderung berhasil, karena dia cenderung mampu. Kalau orang cenderung kalah, karena selalu salah. Self- efficacy lebih terlihat dari mana asalnya menilai diri dari kemampuannya menghadapi masalah.

\subsubsection{Indikator Self-Efficacy}

Menurut Bandura (2007) menyatakan indikator Self-efficacy terdiri dari :

1) Self-efficacy Magnitude (tingkat)

Magnitude atau level yaitu presepsi individu mengenai kemampuannya yang menghasilkan tingkah laku yang akan diukur melalui tingkat tugas yang menunjukkan variasi kesulitan tugas. Tingkatan kesulitan tugas tersebut mengungkapkan dimensi-dimensi kecerdikan, tenaga, akurasi, produktivitas atau regulasi diri yang diperlukan untuk menyebutkan beberapa dimensi prilaku kepuasan individu. Individu yang memiliki tingkat keyakinan tinggi mampu mengerjakan tugas-tugas yang sukar juga memiliki Self-Efficacy yang tinggi sedangkan individu yang memiliki tingkat keyakinan rendah hanya 
mampu mengerjakan tugas-tugas yang mudah serta memiliki Self-Efficacy yang rendah.

2) Self-efficacy Generality (kedewasaan)

Dimensi Generality sejauh mana individu yakin akan kemampuannya dalam berbagai situasi tugas, mulai dari dalam melakukan suatu aktivitas yang biasa dilakukan atau situasi tertentu yang tidak pernah dilakukan hingga dalam serangkaian tugas atau situasi sulit dan bervariasi. Generality merupakan perasaan kemampuan yang ditunjukkan individu pada konterks tugas yang berbeda-beda, baik itu melalui tingkah laku, kognitif dan afektifnya.

3) Self-efficacy Strength (kekuatan)

Strength merupakan kuatnya keyakinan seseorang mengenai kemampuan yang dimilikinya. Strength memperlihatkan kekuatan dan keyakinan diri yang lemah disebabkan tidak terhubung oleh pengalaman, sedangkan orang-orang yang memiliki keyakinan yang kuat, mereka akan bertahan dengan usaha mereka meskipun ada banyak kesulitan dan hambatan. Individu tersebut tidak akan kalah oleh kesulitan, karena kekuatan Self-efficacy tidak selalu berhubungan terhadap pilihan tingkah laku.

Menurut Yunianti Elis, dkk, (2016) merumuskan beberapa indikator self efficacy yaitu :

1) Yakin dapat menyelesaikan tugas tertentu, individu yakin bahwa dirinya mampu menyelesaikan tugas tertentu, yang mana individu sendiirilah yang menetapkan tugas (target) apa yang harus di selesaikan. 
2) Yakin dapat memotivasi diri untuk melakukan tindakan yang diperlukan dalam menyelesaikan tugas, individu mampu menumbuhkan motivasi pada diri sendiri untuk bisa memilih dan melekukan tindakan-tindakan yang di perlukan dalam rangka menyelesaikan tugas.

3) Yakin bahawa dirinya mampu berusaha dengan keras,gigih dan tekun.adanya usaha yang keras dari individu untuk menyelesaikan tugas yang di tetapkan dengan menggunakan segala daya yang di miliki.

4) Yakin bahwa diri mampu menghadapi hambatan dan kesulitan. Individu mampu bertahan saat menghadapi kesulitan dan hambatan yang muncul serta mampu bangkit dari kegagalan.

5) Yakin dapat menyelesaikan tugas yang memiliki range yang luas ataupun sempit (spesifik). Individu yakin bahwa dalam setiap tugas apapun dapat ia selesaikan meskipun itu luas atau spesifik.

Menurut Alwisol (2014) ada beberapa faktor yang mempengaruhi self efficacy yaitu:

1) Pengalaman keberhasilan (mastery experiences), keberhasilan yang sering didapatkan akan meningkatkan efikasi diri yang dimiliki seseorang, sedangkan kegagalan akan menurunkan efikasi dirinya.

2) Pengalaman orang lain (vicarious experiences), pengalaman keberhasilan orang lain yang memiliki kemiripan dengan individu dalam mengerjakan suatu tugas biasanya akan meningkatkan efikasi diri seseorang dalam mengerjakan tugas yang sama. 
3) Persuasi sosial (social persuation), informasi tentang kemampuan yang disampaikan secara verbal oleh seseorang yang berpengaruh biasanya digunakan untuk meyakinkan seseorang bahwa ia cukup mampu melakukan suatu tugas.

4) Keadaan fisiologis dan emosional (physiological and emotional states), kecemasan dan stres yang terjadi dalam diri seseorang ketika melakukan tugas sering diartikan sebagai suatu kegagalan.

\subsubsection{Self Esteem}

Gardner et. al (2031) mendefinisikan self esteem sebagai suatu keyakinan nilai diri sendiri berdasarkan evaluasi diri secara keseluruhan. Persaan-perasaan self esteem, pada kenyataan terbentuk oleh keadaan kita dan bagaimana orang lain memperlakukan kita. Penilaian individu ini diungkapkan dalam sikap-sikap yang dapat bersifat tinggi atau negatif. Self esteem yang tinggi akan membangkitkan rasa percaya diri, penghargaan diri, rasa yakin akan kemampuan diri, rasa bahwa kehadirannya diperlukan di dalam dunia ini. Individu dengan self esteem yang rendah cenderung tidak berani mencari tantangan-tantangan baru dalam hidupnya, lebih senang menghadapi hal-hal yang sudah dikenal dengan baik serta menyenangi hal-hal yang tidak penuh dengan tuntutan, tidak mampu berkomunikasi dengan orang lain, dan cenderung merasa hidupnya tidak bahagia.

Beane (2009) menyatakan bahwa harga diri berhubungan dengan efikasi diri seseorang tentang yang bernilai dalam dirinya. Seseorang yang tidak menghargai atau menghormati dirinya sendiri akan merasa kurang percaya diri dan banyak berjuang dengan segala keterbatasan dirinya, sehingga sering mereka 
terlibat dalam tingkah laku yang salah atau rentan untuk dieksploitasi dan disalahgunakan oleh orang lain. Selanjutnya Beane (2009) menjelaskan bahwa seseorang yang memiliki perasaan menghargai diri yang rendah timbul karena persepsi yang subjektif dan tidak selalu akurat dengan pandangan orang lain. Rasa menghargai diri yang rendah seringkali berasal dari perbandingan yang tidak menyenangkan tentang dirinya sendiri dan orang lain.

Selanjutnya Rosenberg (2011) bahwa individu yang memiliki harga diri tinggi akan menghormati dirinya dan menganggap dirinya sebagai individu yang berguna. Sedangkan individu yang memiliki harga diri yang rendah ia tidak dapat menerima dirinya dan menganggap dirinya tidak berguna dan serba kekurangan. Sedangkan Coopersmith (2014) mengatakan bahwa harga diri (Self Esteem) adalah evaluasi diri yang dibuat seseorang, biasanya untuk dipertahankan, dan sebagian berasal dari interaksi seseorang dengan lingkungannya dan dari sejumlah penghargaan, penerimaan dan perhatian orang lain yang diterimanya.

Menurut Coopersmith (2014), ada empat komponen yang menjadi sumber dalam pembentukan Self Esteem individu. Keempat komponen itu adalah keberhasilan (Successes), Nilai-nilai (value), Aspirasi-aspirasi (Aspirations), dan pendekatan dalam merespon penurunan penilaian terhadap diri (Defences).

Dapat disimpulkan bahwa self esteem menggambarkan sejauh mana individu tersebut menilai dirinya sebagai orang yang memiliki kemampuan, keberartian, berharga, dan kompeten. harga diri tinggi menunjukkan perilaku menerima dirinya apa adanya, percaya diri, puas dengan karakter dan kemampuan diri dan individu yang memiliki harga diri rendah, akan menunjukkan perhargaan 
buruk terhadap dirinya sehingga tidak mampu menyesuaikan diri dengan lingkungan sosial.

\subsubsection{Indikator Self Esteem}

Menurut Coopersmith (2014) terdapat empat aspek yang terkandung dalam Self Esteem, yaitu:

1) Power

Kekuasaasan dalam arti kemampuan untuk mengatur dan mengontrol tingkah laku orang lain. Kemampuan ini ditandai oleh adanya pengakuan dan rasa hormat yang diterima individu dari orang lain dan besarnya sumbangan dari pikiran atau pendapat dan kebenarannya.

2) Significance

Significance atau keberartian adalah adanya kepedulian dan afeksi yang diterima individu dari orang lain. Hal tersebut merupakan penghargaan dan minat dari orang lain dan pertanda penerimaan dan popularitasnya. Keadaan tersebut ditandai oleh kehangatan, keikutsertaan, perhatian, dan kesukaan orang lain terhadapnya.

3) Virtue

Virtue atau kebajikan adalah ketaatan atau mengikuti standar moral dan etika. Kebajikan ditandai oleh ketaatan untuk menjauhi tingkah laku yang harus dihindari dan melakukan tingkah laku yang diperbolehkan atau diharuskan oleh moral atau etika dan agama.

4) Competence 
Kemampuan, dalam arti sukses memenuhi tuntutan prestasi yang ditandai oleh keberhasilan individu dalam mengerjakan bermacam- macam tugas atau pekerjaan dengan baik dari level yang tinggi dan usia yang berbeda.

Menurut Booree (2006), terdapat tiga komponen self esteem pada individu, yaitu:

1) Perasaan diterima (Felling Of Belonging)

Perasaan individu bahwa dirinya merupakan bagian dari suatu kelompok dan dirinya diterima seperti dihargai oleh anggota kelompoknya. Kelompok ini dapat berupa keluarga kelompok teman sebaya, atau kelompok apapun. kelompok tertentu.

2) Perasaan Mampu (Felling Of Competence)

Perasaan dan keyakinan individu akan kemampuan yang ada pada dirinya sendiri dalam mencapai suatu hasil yang diharapkan, misalnya perasaan seseorang pada saat mengalami keberhasilan atau kegagalan.

3) Perasaan Berharga (Felling Of Worth)

Perasaan dimana individu merasa dirinya berharga atau tidak, dimana perasaan ini banyak dipengaruhi oleh pengalaman yang lalu. Perasaan yang dimiliki individu yang sering kali ditampilkan dan berasal dari pernyataan-pernyataan yang sifatnya pribadi seperti pintar, sopan, baik dan lain sebagainya.

Sedangkan menurut Frey dan Carlock (2007), terdapat dua komponen self esteem yang saling berhubungan, yaitu: 
1) Merasa mampu, yaitu perasaan bahwa individu mampu mencapai tujuan yang diinginkannya. Menjadi mampu berarti individu memiliki keyakinan pikiran, perasaan dan perilaku yang sesuai dengan realita dirinya. Apabila individu mampu atau berhasil dalam tujuannya maka harga dirinya meningkat.

2) Merasa berguna, yaitu perasaan individu bahwa ia berguna untuk hidup. Merasa berguna berarti menguatkan diri dan menghormati dirinya sendiri. Individu yang memandang dirinya sebagai individu yang tidak layak akan menurunkan harga dirinya.

\subsubsection{Pengaruh Locus of Control terhadap Kinerja}

Menurut Robbins dan Judge (2014) mendefinisikan Locus of control sebagai tingkat dimana individu yakin bahwa mereka adalah penentu nasib mereka sendiri. Locus of control dapat mempengaruhi kinerja dikarenakan, seseorang yang memiliki kendali yang kuat atas dirinya terhadap peristiwaperistiwa dalam kehidupan dapat mendorong dirinya untuk bekerja keras. Kreitner \& Kinichi (2016), mengatakan bahwa hasil yang dicapai Locus of control internal dianggap berasal dari aktifitas dirinya Sehingga individu tersebut dapat meningkatkan kinerjanya atas dasar keinginannya sendiri untuk mendapatkan hasil kerja yang optimal sesuai dengan apa yang dia upayakan. Hal ini disebut dengan locus of control internal.

Ratno Purnomo (2010) meneliti tentang pengaruh locus of control terhadap kinerja, menyimpulkan locus of control internal berpengaruh terhadap kinerja karyawan. Selanjutnya Sanjiwani dan Wisadha (2016), locus of control berpengaruh positif pada kinerja auditor kantor akuntan publik di provinsi Bali. 
Ridwan (2013) menyimpulkan bahwa, variabel bebas locus of control berpengaruh signifikan terhadap variabel terikat kinerja karyawan. Menezes (2008), internal auditor yang memiliki locus of control internal akan menunjukkan tingkat kinerja yang lebih tinggi

\subsubsection{Pengaruh Self efficacy terhadap Kinerja}

Bandura (2007), mengungkapkan bahwa self-efficacy adalah keyakinan individu mengenai kemampuan dirinya dalam melakukan tugas atau tindakan yang diperlukan untuk mencapai hasil tertentu. Self-efficacy tidak muncul begitu saja dalam diri seseorang (Hjelle dan Zeigeier, 2012). Kepercayaan terhadap kemampuan diri, keyakinan terhadap keberhasilan yang selalu dicapai membuat seseorang bekerja lebih giat dan selalu menghasilkan yang terbaik. Dengan demikian dapat dikatakan bahwa self efficacy dapat meningkatkan kinerja individual.

Hasil penelitian yang dilakukan oleh Stevani Sebayan (2017) menemukan adanya pengaruh antara self efficacy terhadap kinerja. Penelitian juga dilakukan oleh Ari Sinar Deany (2016) dengan hasil bahwa self efficacy memiliki pengaruh terhadap kinerja. Semakin meningkat self efficacy yang dimiliki oleh seseorang maka kinerja juga akan semakin meningkat.

\subsubsection{Pengaruh Self Esteem terhadap Kinerja}

Menurut Baron dan Greenberg (2006) individu dengan self-esteem tinggi percaya bahwa mereka memiliki karakter dan sifat yang diperlukan. Terdapat tiga kemungkinan bagi individu dengan self-esteem yaitu : 1) memiliki tingkat job 
satisfaction dan motivasi yang lebih tinggi, 2) menunjukkan tingkat yang lebih dalam berbagai tugas dan bidang, dan 3) lebih sukses dalam mengidentifikasikan dan memperoleh pekerjaan yang sesuai.

Menurut Beane (2009) seseorang yang merasa dirinya begitu berharga dan berarti cenderung untuk melakukan yang terbaik dalam setiap tugas dan tanggung jawaabnya, baik sebagai anggota organisasi maupun sebagai individual. Dengan demikian maka akan meningkatkan kinerja individualnya.

Penelitian yang dilakukan oleh Stevani sebayan (2017) menemukan adanya hubungan positif antara self esteem dan kinerja individu begitu juga dengan penelitian yang dilakukan oleh Ari Sinar Deany (2016) juga menemukan adnaya pengaruh antara self esteem dengan kinerja. Semakin tinggi self esteem yang dimiliki oleh seorang karyawan akan meningkatkan kinerja individu karena adanya tingkat harga diri yang membuat mereka merasa dihargai sehingga karyawan berusaha bekerja dengan lebih baik dan kinerja semakin meningkat. Sebaliknya, jika harga diri (self esteem) yang dimiliki seorang karyawan rendah maka kinerjanya akan semakin menurun.

Berdasarkan kerangka analisis di atas dapat dilihat bahwa adanya pengaruh dari variabel locus of control (X1), Self efficacy (X2) dan Self esteem (X3) terhadap Kinerja (Y).

\subsection{Defenisi Operasional dan Pengukuran Variabel}

Adapun defenisi operasional dan pengukuran variabel dalam penelitian ini adalah sebagai berikut : 
Tabel 2.2

Defenisi Operasional dan Pengukuran Variabel

\begin{tabular}{|c|c|c|c|c|c|}
\hline No & Variabel & Defenisi & Indikator & $\begin{array}{c}\text { Alat } \\
\text { Ukur }\end{array}$ & Skala \\
\hline 1 & $\begin{array}{l}\text { Locus of } \\
\text { control } \\
\left(\mathrm{X}_{1}\right)\end{array}$ & $\begin{array}{l}\text { Locus of control sebagai } \\
\text { tingkat dimana individu } \\
\text { yakin bahwa mereka adalah } \\
\text { penentu nasib mereka } \\
\text { sendiri. Locus of control } \\
\text { dipengaruhi oleh faktor } \\
\text { internal dan eskternal } \\
\text { Robbins dan Judge (2014) }\end{array}$ & $\begin{array}{l}\text { a. Locus of control } \\
\text { internal : } \\
\text { - } \quad \text { suka bekerja keras } \\
\text { - } \quad \text { memiliki iniiatif } \\
\text { yang tinggi } \\
\text { - } \text { selalu ebrusaha } \\
\text { - } \quad \text { selalu mencoba } \\
\text { untuk befikir } \\
\text { - } \quad \text { selalu mempunyai } \\
\text { persepsi } \\
\text { Locus of control } \\
\text { eksternal } \\
\text { - kurang memiliki } \\
\text { inisiatif } \\
\text { - kurang suka } \\
\text { berusaha } \\
\text { - kurang mencari } \\
\text { informasi } \\
\text { Robbin dan Judge (2014) }\end{array}$ & Kuesioner & $\begin{array}{l}\text { Skala } \\
\text { Likert }\end{array}$ \\
\hline 2 & $\begin{array}{l}\text { Self- } \\
\text { efficancy } \\
\left(\mathrm{X}_{2}\right)\end{array}$ & $\begin{array}{l}\text { Self-efficacy adalah } \\
\text { keyakinan individu } \\
\text { mengenai kemampuan } \\
\text { dirinya dalam melakukan } \\
\text { tugas atau tindakan yang } \\
\text { diperlukan untuk mencapai } \\
\text { hasil tertentu. } \\
\text { Bandura (2007) }\end{array}$ & $\begin{array}{ll}\text { a. } & \text { Self-efficacy } \\
& \text { Magnitude (tingkat) } \\
\text { b. Self-efficacy } \\
\text { Generality } \\
\text { (kedewasaan) } \\
\text { c. Self-efficacy Strength } \\
\text { (kekuatan) } \\
\text { Bandura (2007) }\end{array}$ & Kuesioner & $\begin{array}{l}\text { Skala } \\
\text { Likert }\end{array}$ \\
\hline 3 & $\begin{array}{l}\text { Self } \\
\text { Esteem } \\
\left(\mathrm{X}_{2}\right)\end{array}$ & $\begin{array}{l}\text { Self esteem sebagai suatu } \\
\text { keyakinan nilai diri sendiri } \\
\text { berdasarkan evaluasi diri } \\
\text { secara keseluruhan. } \\
\text { Gardner et. al (2013) }\end{array}$ & $\begin{array}{l}\text { a. Power } \\
\text { b. Significance } \\
\text { c. Virtue } \\
\text { d. Competence } \\
\text { Coopersmith (2014) }\end{array}$ & $\begin{array}{l}\text { Kuesion } \\
\text { er }\end{array}$ & $\begin{array}{l}\text { Skala } \\
\text { Liker } \\
\mathrm{t}\end{array}$ \\
\hline 4 & $\begin{array}{l}\text { Kinerja } \\
(\mathrm{Y})\end{array}$ & $\begin{array}{lr}\text { Kinerja merupakan } & \text { hasil } \\
\text { kerja secara kualitas } & \text { dan } \\
\text { kuantitas yang dicapai oleh } & \text { dalam } \\
\text { seseorang } & \text { dungsinya } \\
\text { melaksanakan } & \text { dengan } \\
\text { sesuai } & \text { yang } \\
\text { tanggungjawab } & \\
\text { diberikan kepadanya. } & \\
\text { Mangkunegara (2008) }\end{array}$ & $\begin{array}{l}\text { a) Kualitas Pekerjaan } \\
\text { (Quality of Work) } \\
\text { b) Kuantitas Pekerjaan } \\
\text { (Quantity of Work) } \\
\text { c) Pengetahuan Pekerjaan } \\
\text { (Job Knowledge) } \\
\text { d) Kerjasama Tim } \\
\text { (Teamwork) } \\
\text { e) Kreatifitas (Creativity) } \\
\text { Mangkunegara (2008) }\end{array}$ & $\begin{array}{l}\text { Kuesione } \\
\mathrm{r}\end{array}$ & $\begin{array}{l}\text { Skala } \\
\text { Likert }\end{array}$ \\
\hline
\end{tabular}




\subsection{Hipotesis}

$\mathrm{H}_{1}$ : Diduga adanya pengaruh yang positif dan signifikan antara locus of control terhadap kinerja perawat pada RSUD Hasanuddin Damrah Manna

$\mathrm{H}_{3}$ : Diduga adanya pengaruh yang positif dan signifikan antara selfefficacy terhadap kinerja perawat pada RSUD Hasanuddin Damrah Manna

$\mathrm{H}_{3}$ : Diduga adanya pengaruh yang positif dan signifikan antara selft estem terhadap kinerja perawat pada RSUD Hasanuddin Damrah Manna

$\mathrm{H}_{4} \quad$ : Diduga adanya pengaruh yang positif dan signifikan secara beı sama antara locus of control, self-efficacy dan self esteem terhadap kinerja perawat pada RSUD Hasanuddin Damrah Manna

\section{BAB III}

\section{METODE PENELITIAN}

\subsection{Tempat dan Waktu Penelitian}

Dalam proposal ini peneliti mengambil tempat penelitian RSUD Hasanuddin Damrah Manna dan penelitian akan dilaksanakan pada bulan Januari 2020.

\subsection{Jenis Penelitian}

Jenis penelitian yang digunakan dalam penelitian ini adalah penelitian kuantitatif dengan pendekatan deskriptif. Metode penelitian kuantitatif merupakan salah satu jenis penelitian yang spesifikasinya adalah sistematis, terencana dan 
terstruktur dengan jelas sejak awal hingga pembuatan desain penelitiannya. Menurut Sugiyono (2013), metode penelitian kuantitatif dapat diartikan sebagai metode penelitian yang berlandaskan pada filsafat positivisme, digunakan untuk meneliti pada populasi atau sampel tertentu, teknik pengambilan sampel pada umumnya dilakukan secara random, pengumpulan data menggunakan instrumen penelitian, analisis data bersifat kuantitatif/statistik dengan tujuan untuk menguji hipotesis yang telah ditetapkan. Penelitian ini menggunakan pendekatan deskriptif dengan tujuan untuk mendeskripsikan objekpenelitian atupun hasil penelitian. Adapun pengertian deskriptif menurut Sugiyono (2013) adalah metode yang berfungsi untuk mendeskripsikan atau memberi gambaran terhadap objek yang diteliti melalui data atau sampel yang telah terkumpul sebagimana adanya, tanpa melakukun analisis dan membuat kesimpulan yang berlaku umum.

\subsection{Populasi dan Sampel}

\subsubsection{Populasi}

Menurut Sugiyono (2013), populasi adalah wilayah generalisasi yang terdiri atas objek atau subjek yang mempunyai kualitas dan karakteristik tertentu yang ditetapkan oleh peneliti untuk dipelajari dan kemudian ditarik kesimpulannya. Berdasarkan kualitas dan ciri tersebut, populasi dapat dipahami sebagai sekelompok individu atau objek pengamatan yang minimal memiliki satu persamaan karakteristik. Populasi dalam penelitian ini adalah seluruh perawat yang bekerja pada RSUD Hasanuddin Damrah Manna dan telah menjadi PNS sebanyak 162 orang perawat.

\subsubsection{Sampel}


Sampel adalah bagian dari jumlah dan karakteristik yang dimiliki oleh populasi tersebut (Sugiyono, 2013). Sampel dalam penelitian ini sebanyak 162 orang perawat yang bekerja pada RSUD Hasanuddin Damrah Manna dan telah menjadi PNS, karena semua populasi dalam penelitian ini dijadikan sampel, maka metode pengambilan sampel dengan cara sensus. Menurut Sugiyono (2013) metode sensus atau jenuh adalah teknik penentuan sampel bila semua anggota populasi digunakan dalam penelitian.

\subsection{Teknik Pengumpulan Data}

Metode pengumpulan data dimaksudkan untuk memperoleh informasi yang relevan, akurat dan reliabel. Metode pengumpulan data yang di gunakan adalah :

a. Observasi:

Menurut Sugiyono (2013) metode observasi adalah metode pengumpulan data di mana penyelidik mengadakan pengamatan secara langsung terhadap situasi yang kompleks dan merupakan suatu proses yang tersusun dari berbagai proses biologis dan psikologis yang mengutamakan pengamatan dan ingatan

b. Kuesioner

Kuesioner merupakan teknik pengumpulan data yang dilakukan dengan cara memberi seperangkat pertanyaan atau pernyataan tertulis kepada responden untuk dijawabnya (Sugiyono, 2013). Data yang diperoleh dalam penelitian ini didapatkan langsung dari pengisian kuesioner (angket) yang ditujukan kepada responden. Pertanyaan-pertanyaan pada angket dibuat dengan skala Likert dengan 1-5. Skor 1-5 digunakan peneliti karena lebih sederhana dan memiliki nilai tengah yang digunakan untuk menjelaskan keragu-raguan atau netral 
dalam memilih jawaban. Untuk analisis kuantitatif, maka jawaban itu dapat diberi skor yang ditunjukkan pada tabel berikut :

Tabel 3.1

Skala Likert

\begin{tabular}{|l|c|}
\hline Pilihan Jawaban & Skor \\
\hline Sangat Tidak Setuju (STS) & 1 \\
\hline Tidak Setuju (TS) & 2 \\
\hline Netral (N) & 3 \\
\hline Setuju (S) & 4 \\
\hline Sangat Setuju (SS) & 5 \\
\hline
\end{tabular}

Sumber : Sugiyono, 2013

\subsection{Instrumen Penelitian}

Untuk menguji keakuratan kuesioner maka dilakukan pengujian instrument terhadap 30 orang sampel diluar sampel penelitian, adapun uji intrumen yang digunakan adalah sebagai berikut :

\section{a. Uji Validitas}

Uji validitas digunakan untuk mengukur sah atau tidaknya suatu kuesioner. Suatu kuesioner dikatakan valid jika pada kuesioner mampu mengungkapkan sesuatu yang akan diukur oleh kuesioner tersebut. Pengujian validitas ini menggunakan Pearson Correlation yaitu dengan cara menghitung korelasi antara nilai yang diperoleh dari pertanyaan-pertanyaan. Suatu pertanyaan dikatakan valid jika tingkat signifikansinya berada di bawah 0,05. (Ghozali, 2012).

\section{b. Uji Reliabilitas}


Uji Reliabilitas sebenarnya adalah alat untuk mengukur suatu kuesioner yang merupakan indikator dari variabel atau konstruk. Suatu kuesioner dikatakan reliabel atau handal jika jawaban seseorang terhadap pertanyaan adalah konsisten atau stabil dari waktu ke waktu. Butir kuesioner dikatakan reliabel (layak) jika cronbach's alpha $>0,06$ dan dikatakan tidak reliabel jika cronbach's alpha $<0,06$. (Ghozali, 2012).

\subsection{Uji Asumsi Klasik}

\subsubsection{Uji Normalitas}

Uji normalitas bertujuan untuk menguji apakah dalam sebuah model regresi, variabel dependen dan variabel independen mempunyai distribusi normal atau tidak (Ghozali, 2012). Uji ini digunakan untuk mendapatkan kepastian terpenuhinya syarat normalitas yang akan menjamin dapat dipertanggungjawabkannya langkahlangkah analisis statistik sehingga kesimpulan yang diambil dapat dipertanggungjawabkan. Metode yang dipakai untuk mendeteksi kenormalan model regresi digunakan uji Kolmogorov-Smirnov. Data-data yang berdistribusi normal memiliki nilai probabilitas > 0,05, sebaliknya, data berdistribusi tidak normal jika memiliki nilai probabilitas $<0,05$ (Ghozali, 2012).

\subsubsection{Uji Multikolenieritas}

Melihat ada atau tidaknya korelasi yang tinggi antara variabel-variabel bebas dalam suatu model regresi linier berganda. Jika ada korelasi yang tinggi di antara variabel terikatnya menjadi terganggu.

Alat statisatik yang sering digunakan untuk menguji gangguan multikolinearitas adalah dengan variance inflation factor (VIF) dan tolerance. Nilai 
cut off yang digunakan untuk mengidentifikasi adanya multikolenieritas adalah jika nilai VIF $>10$ atau nilai tolerance $<0,1$.

\subsubsection{Uji Heteroskedastisitas}

Uji heterokesdatisitas bertujuan untuk mengetahui apakah dalam sebuah model regresi terjadi ketidaksamaan varians dari residual suatu pengamatan ke pengamatan lain. Jika varians dari residual suatu pengamatan ke pengamatan yang lain tetap, maka disebut homoskedastisitas, sementara itu, untuk varians yang berbeda disebut heteroskedastisitas (Umar, 2011:189).

Cara menguji ada tidaknya heterokedastisitas yaitu dengan menggunakan analisis uji glejser dilakukan dengan cara meregresikan antara variabel independent dengan nilai absolut residualnya. Jika nilai signifikansi antara variabel independent dengan absolut residual lebih dari 0,05 maka tidak terjadi masalah heteroskedastisitas.

\subsection{Analisis Terhadap Variabel Penelitian}

Perhitungan rata-rata dari responden dengan menggunakan rumus:

$$
\text { Rumus }=X=\frac{\sqrt{x}}{n}
$$

Untuk menilai persepsi responden atas variabel penelitian, maka perlu ditentukan reng interval dari kelas interval dengan rumus sebagai berikut :

Interval kelas $=\frac{\text { bobot tertinggi }- \text { bobot terendah }}{\text { Jumlah Kelas }}=\frac{5-1}{5}=0,8$

Setelah besarnya interval diketahui, kemudian dibuat rentang skala sehingga dapat ditentukan kriteria penilaian persepsi responden terhadap variabel-variabel. 
Maka kriteria standar penilaian variabel dan indikator variabel adalah sebagai berikut:

1. $1,00-1,80=$ Sangat Tidak Baik

2. $1,81-2,60=$ Tidak Baik

3. $2,61-3,40=$ Cukup Baik

4. $3,41-4,20=$ Baik

5. $4,21-5,00=$ Sangat Baik

\subsection{Teknik Analisis Data}

\subsection{1 . Regresi Linier Berganda}

Model regresi adalah model yang digunakan untuk menganalisis pengaruh dari berbagai variabel independen terhadap satu variabel dependen (Sugiyono, 2013). Bentuk umum persamaan regresi berganda adalah sebagai berikut (Sugiyono, 2013) :

$\mathrm{Y}=\mathrm{a}+\mathrm{b}_{1} \mathrm{X}_{1}+\mathrm{b}_{2} \mathrm{X}_{2}+\mathrm{b}_{3} \mathrm{X}_{3}+\mathrm{e}$

Keterangan :

$\mathrm{Y}=$ Kinerja

$\mathrm{X}_{1}=\quad$ locus of control

$\mathrm{X}_{2}=\quad$ selft eficancy

$\mathrm{X}_{3}=$ selft esetem

$\mathrm{a}=$ Nilai konstanta

Analisa regresi berganda ini dimaksudkan untuk mengetahui tingkat pengaruh dari masing-masing variabel bebas terhadap variabel tergantung secara 
kuantitatif. Besarnya pengaruh dari masing-masing variabel bebas tersebut dapat diperkirakan dengan melakukan interpretasi angka koefisien regresi partial b.

\subsubsection{Koefisien Determinasi}

Koefisien determinasi digunakan untuk mengukur seberapa jauh kemampuan model dalam menerangkan variabel dependen. Nilai koefesien determinasi adalah antara 0 dan 1 . Nilai $\mathrm{R}^{2}$ yang kecil berarti kemampuan variabel - variabel independen dalam menerangkan variabel dependen sangat terbatas. Nilai yang mendekati 1 berarti variabel independen memberikan hampir semua informasi yang dibutuhkan untuk memprediksi variasi variabel dependen. Adapun rumus yang digunakan untuk menentukan koefesien determinasi adalah :

$$
K d=(r)^{2} \times 100 \%
$$

( Sugiyono, 2013)

Kelemahan R2 adalah bisa terhadap jumlah variabel independen yang dimasukkan ke dalam model. Setiap tambahan satu variabel independen maka $\mathrm{R}^{2}$ pasti akan meningkat walaupun belum tentu variabel yang ditambahkan berpengaruh secara signifikan terhadap variabel dependen. Oleh karena itu, digunakan nilai adjusted $\mathrm{R}^{2}$ karena nilai adjusted $\mathrm{R}^{2}$ dapat naik atau turun apabila satu variabel independen ditambahkan ke dalam model.

\subsubsection{Pengujian Hipotesis}

\subsubsection{Uji T (Partial)}

Menurut Ghozali (2012) Uji beda t-test digunakan untuk menguji seberapa 
jauh pengaruh variabel independen yang digunakan dalam penelitian ini secara individual dalam menerangkan variabel dependen secara parsial.

Untuk menguji hipotesis tersebut digunakan statistik t yang dihitung dengan cara sebagai berikut :

$t=\frac{b}{S b}$

Sugiyono (2013)

Dimana $\mathrm{b}$ adalah nilai parameter dan $\mathrm{Sb}$ adalah standart error dari b. Standart error dari masing-masing paramater dihitung dari akar varians masing-masing.

Dasar pengambilan keputusan digunakan dalam uji t adalah sebagai berikut:

1. Jika nilai probabilitas $t_{\text {hitung }}<t_{\text {tabel }}$, maka hipotesis ditolak. Hipotesis ditolak mempunyai arti bahwa variabel independen tidak berpengaruh signifikan terhadap variabel dependen.

2. Jika nilai $t_{\text {hitung }}>t_{\text {tabel}}$, maka hipotesis diterima. Hipotesis diterima mempunyai arti bahwa variabel independen berpengaruh signifikan terhadap variabel dependen.

\subsubsection{Uji F (Simultan)}

Menurut Ghozali (2012) Uji Statistik F pada dasarnya menunjukkan apakah semua variabel independen atau variabel bebas yang dimasukkan dalam model mempunyai pengaruh secara bersama-sama terhadap variabel dependen atau variabel terikat. Untuk menguji kebenaran hipotesis alternatif dilakukan uji $\mathrm{F}$ dengan rumus sebagai berikut: 


$$
F=\frac{R^{2} / k}{\left(1-R^{2}\right) /(n-k-1}
$$

Sugiyono (2013:235)

Untuk menguji hipotesis ini digunakan statistik $F$ dengan kriteria pengambilan keputusan sebagai berikut:

1. Jika nilai $f_{\text {hitung }}<f_{\text {tabel, }}$ maka hipotesis ditolak. Hipotesis ditolak mempunyai arti bahwa variabel independen tidak berpengaruh signifikan terhadap variabel dependen secara serempak.

2. Jika nilai $f_{\text {hitung }}>f_{\text {tabel, }}$, maka hipotesis diterima. Hipotesis diterima memp arti bahwa variabel independen berpengaruh signifikan terhadap variabel dependen secara serempak.

\section{BAB IV}

\section{HASIL PENELITIAN DAN PEMBAHASAN}

\subsection{Hasil Penelitian}

\subsubsection{Uji Asumsi Klasik}

\subsubsection{Uji Normalitas}

Kriteria dalam pengambilan keputusan adalah sebagai berikut :

1. Jika data menyebar disekitar garis diagonal dan mengikuti arah, maka model regresi memenuhi asumsi normalitas.

2. Jika menyebar jauh dari garis diagonal, maka model regresi tidak memenuhi asumsi normalitas data

\section{Gambar 4.1.}

\section{Grafik Uji Normalitas}




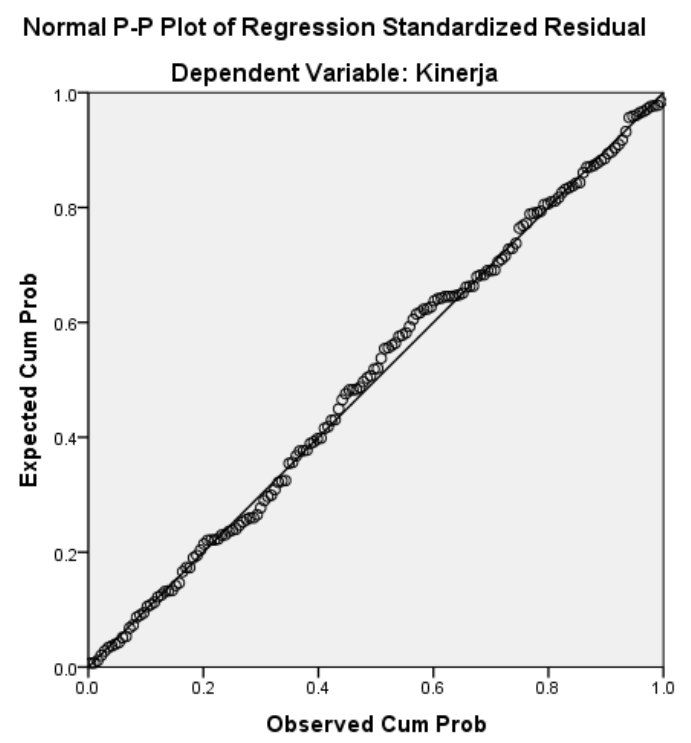

Sumber : Hasil Penelitian (output SPSS), 2020

Berdasarkan gambar grafik diatas tampak bahwa data menyebar disekitar garis diagonal dan mengikuti arah garis. Maka model regresi ini memenuhi asumsi normalitas.

\subsubsection{Uji Multikolinearitas}

Uji multikolinearitas digunakan untuk mengetahui apakah model regresi yang diajukan telah ditemukan korelasi kuat antar variabel independen. Untuk mendeteksi apakah model regresi linier mengalami multikolinieritas. Banyak penelitian menyebutkan jika nilai tolerance $<0,10$ atau nilai VIF $>10$ berarti terdapat multikolinearitas.

Tabel 4.5

Uji Multikolinieritas 


\begin{tabular}{|c|c|c|c|c|c|c|c|c|}
\hline \multicolumn{9}{|c|}{ Coefficients $^{a}$} \\
\hline \multirow{2}{*}{\multicolumn{2}{|c|}{ Model }} & \multicolumn{2}{|c|}{ Unstandardized Coefficients } & \multirow{2}{*}{$\begin{array}{c}\begin{array}{c}\text { Standardized } \\
\text { Coefficients }\end{array} \\
\text { Beta }\end{array}$} & \multirow[b]{2}{*}{$t$} & \multirow[b]{2}{*}{ Sig. } & \multicolumn{2}{|c|}{ Collinearity Statistics } \\
\hline & & $\mathrm{B}$ & Std. Error & & & & Tolerance & VIF \\
\hline \multirow[t]{4}{*}{1} & (Constant) & 10.422 & 3.568 & & 2.921 & .004 & & \\
\hline & Locus of control & .172 & .061 & .189 & 2.796 & .006 & .932 & 1.073 \\
\hline & Self Efficacy & .257 & .064 & .287 & 3.993 & .000 & .830 & 1.205 \\
\hline & Selt Esteem & .335 & .082 & .300 & 4.080 & .000 & .792 & 1.263 \\
\hline
\end{tabular}

a. Dependent Variable: Kinerja

Sumber : Hasil Penelitian (output SPSS), 2020

Dari hasil tabel diatas diketahui bahwa nilai tolerance lebih besar dari 0,1 dan nilai VIF lebih kecil dari 10. Maka bisa diduga bahwa antar variabel independen tidak terjadi persoalan multikoliniearitas.

\subsubsection{Uji Heterokesdatisitas}

Cara menguji ada tidaknya heterokedastisitas yaitu dengan menggunakan analisis uji glejser dilakukan dengan cara meregresikan antara variabel independent dengan nilai absolut residualnya. Jika nilai signifikansi antara variabel independent dengan absolut residual lebih dari 0,05 maka tidak terjadi masalah heteroskedastisitas. Adapun hasil uji heterokedatisitas seperti pada table berikut :

Tabel 4.6

Uji Heterokedisitas

\begin{tabular}{|c|c|c|c|c|c|c|}
\hline \multicolumn{7}{|c|}{ Coefficients $^{a}$} \\
\hline \multirow{2}{*}{\multicolumn{2}{|c|}{ Model }} & \multicolumn{2}{|c|}{ Unstandardized Coefficients } & \multirow{2}{*}{$\begin{array}{c}\text { Standardized } \\
\text { Coefficients } \\
\text { Beta } \\
\end{array}$} & \multirow[b]{2}{*}{$\mathrm{t}$} & \multirow[b]{2}{*}{ Sig. } \\
\hline & & $\mathrm{B}$ & Std. Error & & & \\
\hline \multirow[t]{4}{*}{1} & (Constant) & 3.438 & 2.060 & & 1.669 & .097 \\
\hline & Locus of control & -.047 & .035 & -.109 & -1.334 & .184 \\
\hline & Self Efficacy & .010 & .037 & .024 & .281 & .779 \\
\hline & Selt Esteem & .005 & .047 & .009 & .096 & .924 \\
\hline
\end{tabular}

a. Dependent Variable: Abs_RES

Sumber : Hasil Penelitian, 2020 
Berdasarkan Tabel 4.6 di atas dapat dilihat bahwa nilai signifikan dari semua variable memiliki nilai lebih besar dari 0,05. Maka dapat disimpulkan bahwa tidak terjadi heterokedisitas terhadap semua variable.

\subsubsection{Analisis Tanggapan Responden Terhadap Variabel Penelitian}

Uraian berikut ini menggambarkan tentang jawaban responden atas pertanyaan yang diajukan melalui kuesioner. Skala yang digunakan dalam penelitian ini adalah skala Likert dengan jenjang 1-5. Selanjutnya penentuan kelas atas jawaban responden terhadap variabel penelitian berdasarkan skor, sebagai berikut:

Nilai terendah dari kelas adalah 1 x $1=1$

Nilai tertinggi dari kelas adalah $5 \times 1=5$

Interval kelas adalah $(5-1): 5=0,8$

Maka kriteria standar penilaian variable dan indikator variable adalah sebagai berikut:

$1,00-1,80=$ tidak baik

$1,81-2,60=$ kurang baik

$2,61-3,40=$ cukup baik

$3,41-4,20=$ baik

$4,21-5,00=$ sangat baik

\subsubsection{Tanggapan Responden Terhadap Variabel Locus of Control}

Locus of Control atau lokus pengendalian yang merupakan kendali individu atas pekerjaan mereka dan kepercayaan mereka terhadap keberhasilan diri. Komposisi jawaban responden terhadap variable locus of control adalah:

\section{Tabel 4.7}


Tanggapan Responden Terhadap Variabel Locus of Control

\begin{tabular}{|c|c|c|c|c|c|c|c|c|c|c|}
\hline \multirow{2}{*}{ No } & \multirow{2}{*}{ Pernyataan } & \multicolumn{5}{|c|}{ Tanggapan Responden } & \multirow{2}{*}{$\begin{array}{c}\text { Respo } \\
\text { nden }\end{array}$} & \multirow{2}{*}{$\begin{array}{l}\text { Total } \\
\text { Skor }\end{array}$} & \multirow{2}{*}{ Rata-Rata } & \multirow{2}{*}{ Kriteria } \\
\hline & & STS & TS & $\mathrm{N}$ & $\mathrm{S}$ & SS & & & & \\
\hline 1 & $\begin{array}{l}\text { Saya suka bekerja keras dalam } \\
\text { melakukan tugas yang diberikan } \\
\text { oleh Rumah Sakit. }\end{array}$ & 0 & 0 & 15 & 120 & 27 & 162 & 660 & 4.07 & Baik \\
\hline 2 & $\begin{array}{l}\text { Apa yang saya peroleh bukan } \\
\text { karena keberuntungan, tetapi } \\
\text { karena inisiatif saya yang tinggi } \\
\text { dalam bekerja. }\end{array}$ & 0 & 1 & 62 & 83 & 16 & 162 & 600 & 3.70 & Baik \\
\hline 3 & $\begin{array}{l}\text { Saya mampu memecahkan masalah } \\
\text { yang akan terjadi dalam } \\
\text { menyeles aikan pekerjaan. }\end{array}$ & 0 & 0 & 39 & 100 & 23 & 162 & 632 & 3.90 & Baik \\
\hline 4 & $\begin{array}{l}\text { Hidup saya ditentukan oleh } \\
\text { tindakan saya sendiri, maka itu } \\
\text { saya berfikir seefektif mungkin. }\end{array}$ & 0 & 0 & 13 & 118 & 31 & 162 & 666 & 4.11 & Baik \\
\hline 5 & $\begin{array}{l}\text { Segala yang dicapai dalam hidup } \\
\text { saya adalah hasil dari usaha yang } \\
\text { telah saya lakukan sendiri. }\end{array}$ & 0 & 0 & 17 & 111 & 34 & 162 & 665 & 4.10 & Baik \\
\hline 6 & $\begin{array}{l}\text { Berpendapat bahwa kesuksesan } \\
\text { dan kegagalan bukan merupakan } \\
\text { takdir }\end{array}$ & 0 & 0 & 21 & 105 & 36 & 162 & 663 & 4.09 & Baik \\
\hline 7 & $\begin{array}{l}\text { Memiliki pandangan bahwa dalam } \\
\text { hidup adanya keberuntungan }\end{array}$ & 0 & 0 & 11 & 104 & 47 & 162 & 684 & 4.22 & $\begin{array}{l}\text { Sangat } \\
\text { Baik }\end{array}$ \\
\hline 8 & $\begin{array}{l}\text { Memiliki perasaan bahwa tingkat } \\
\text { keberhasilan tidak ditentukan oleh } \\
\text { status sosial }\end{array}$ & 0 & 2 & 5 & 105 & 50 & 162 & 689 & 4.25 & $\begin{array}{l}\text { Sangat } \\
\text { Baik }\end{array}$ \\
\hline 9 & $\begin{array}{l}\text { Tidak mengharapkan bantuan } \\
\text { orang lain dalam bekerja }\end{array}$ & 0 & 11 & 54 & 73 & 24 & 162 & 596 & 3.68 & Baik \\
\hline 10 & $\begin{array}{l}\text { Selalu memiliki inis iatif dalam } \\
\text { memecahkan masalah }\end{array}$ & 0 & 0 & 22 & 104 & 36 & 162 & 662 & 4.09 & Baik \\
\hline \multicolumn{8}{|c|}{$\begin{array}{r}\text { Rata- Rata } \\
\end{array}$} & 6517 & 4.02 & Baik \\
\hline
\end{tabular}

Sumber : Hasil Penelitian dan Diolah, 2020

Berdasarkan tabel di atas dapat dilihat bahwa rata-rata tanggapan reponden terhadap variabel locus of control sebesar 4,02 dengan kriteria penilaian baik karena angka tersebut terletak pada interval 3,41 - 4,20. Hal ini menggambarkan bahwa locus of control perawat yang bekerja pada RSUD Hasanuddin Damrah Manna sudah baik..

Penilian tertinggi untuk variabel locus of control dapat dilihat pada indikator "Memiliki perasaan bahwa tingkat keberhasilan tidak ditentukan oleh 
status sosial" dengan skor sebesar 4,25 pada penilaian sangat baik. Hal ini menggambarkan bahwa perawat yang bekerja pada RSUD Hasanuddin Damrah Manna memiliki perasaah bahwa keberhasilan yang mereka capai dalam bekerja bukan disebabkan karena status social tetapi dikarenankan kemampuan yang dimiliki oleh perawat.

Sedangkan pernyataan terendah untuk variabel locus of control terlihat pada indikator "Tidak mengharapkan bantuan orang lain dalam bekerja", dengan skor sebesar 3,68 pada kategori baik. Hal ini menjelaskan bahwa perawat tidak mampu bekerja sendiri dan masih membutuhkan bantuan dari rekan kerjanya dalam memberikan perawatan semaksimal mungkin kepada pasien.

\subsubsection{Tanggapan Responden Terhadap Variabel Self Efficacy}

Self efficacy adalah sebuah keyakinan tentang kemampuannya, seseorang dapat melaksanakan pekerjaannya dengan sukses karena melihat peluangnya dengan beberapa tindakannya sehingga memperoleh hasil yang dicapai. Adapun tanggapan responden terhadap serlf efficacy seperti pada table berikut ini : 
Tabel 4.8

Tanggapan Responden Terhadap Variabel Self Efficacy

\begin{tabular}{|c|c|c|c|c|c|c|c|c|c|c|}
\hline \multirow{2}{*}{ No } & \multirow{2}{*}{ Pernyataan } & \multicolumn{5}{|c|}{ Tanggapan Responden } & \multirow{2}{*}{$\begin{array}{c}\text { Respo } \\
\text { nden }\end{array}$} & \multirow{2}{*}{$\begin{array}{l}\text { Total } \\
\text { Skor }\end{array}$} & \multirow{2}{*}{ Rata-Rata } & \multirow{2}{*}{ Kriteria } \\
\hline & & STS & TS & $\mathrm{N}$ & $\mathrm{S}$ & SS & & & & \\
\hline 1 & $\begin{array}{l}\text { Secara keseluruhan ada kepuasan } \\
\text { terhadap diri sendiri }\end{array}$ & 0 & 1 & 46 & 99 & 16 & 162 & 616 & 3.80 & Baik \\
\hline 2 & $\begin{array}{l}\text { Memiliki pikiran akan manfaat diri } \\
\text { terhadap orang lain }\end{array}$ & 0 & 0 & 28 & 109 & 25 & 162 & 645 & 3.98 & Baik \\
\hline 3 & $\begin{array}{l}\text { Memiliki banyak kualitas yang } \\
\text { bagus }\end{array}$ & 1 & 10 & 64 & 72 & 15 & 162 & 576 & 3.56 & Baik \\
\hline 4 & $\begin{array}{l}\text { Mampu untuk melakukan kegiatan } \\
\text { begitu pula dengan kebanyakan } \\
\text { orang lain }\end{array}$ & 0 & 4 & 39 & 86 & 33 & 162 & 634 & 3.91 & Baik \\
\hline 5 & $\begin{array}{l}\text { Tidak mempunyai sesuatu untuk } \\
\text { dibanggakan }\end{array}$ & 1 & 11 & 30 & 92 & 28 & 162 & 621 & 3.83 & Baik \\
\hline 6 & Merasa tidak berguna sama sekali & 0 & 11 & 30 & 72 & 49 & 162 & 645 & 3.98 & Baik \\
\hline 7 & $\begin{array}{l}\text { Merasa dirinya berguna, paling } \\
\text { tidak sama dengan orang lain }\end{array}$ & 0 & 1 & 17 & 111 & 33 & 162 & 662 & 4.09 & Baik \\
\hline 8 & Memiliki rasa hormat & 0 & 2 & 40 & 82 & 38 & 162 & 642 & 3.96 & Baik \\
\hline 9 & $\begin{array}{l}\text { Mempunyai sikap positif terhadap } \\
\text { diri sendiri }\end{array}$ & 0 & 1 & 40 & 83 & 38 & 162 & 644 & 3.98 & Baik \\
\hline 10 & Merasa cenderung gagal & 0 & 2 & 36 & 86 & 38 & 162 & 646 & 3.99 & Baik \\
\hline \multicolumn{8}{|c|}{ Rata- Rata } & 6331 & 3.91 & Baik \\
\hline
\end{tabular}

Sumber : Hasil Penelitian dan Diolah, 2020

Berdasarkan tabel di atas dapat dilihat bahwa rata-rata tanggapan reponden terhadap variabel self efficacy sebesar 3,91 dengan kriteria penilaian baik karena angka tersebut terletak pada interval 3,41 - 4,20. Hal ini menggambarkan bahwa self efficacy perawat yang bekerja pada RSUD Hasanuddin Damrah Manna sudah baik..

Penilian tertinggi untuk variabel self efficacy dapat dilihat pada indikator "Merasa dirinya berguna, paling tidak sama dengan orang lain" dengan skor sebesar 4,09 pada penilaian baik. Hal ini menggambarkan bahwa perawat yang bekerja pada RSUD Hasanuddin Damrah Manna memiliki tingkar rasa percaya diri terhadap kemampuan yang mereka miliki, karena meraka merasa dirinya berguna 
untuk orang lain terutama untuk pasien yang sedang dirawat di RSUD Hasanuddin Damrah Manna.

\subsubsection{Tanggapan Responden Terhadap Variabel Self Esteem}

Tabel 4.9

Tanggapan Responden Terhadap Variabel Self Esteem

\begin{tabular}{|c|c|c|c|c|c|c|c|c|c|c|}
\hline \multirow{2}{*}{ No } & \multirow{2}{*}{ Pernyataan } & \multicolumn{5}{|c|}{ Tanggapan Responden } & \multirow{2}{*}{$\begin{array}{c}\text { Respo } \\
\text { nden }\end{array}$} & \multirow{2}{*}{$\begin{array}{l}\text { Total } \\
\text { Skor }\end{array}$} & \multirow{2}{*}{ Rata-Rata } & \multirow{2}{*}{ Kriteria } \\
\hline & & STS & TS & $\mathrm{N}$ & $\mathrm{S}$ & SS & & & & \\
\hline 1 & $\begin{array}{l}\text { Mampu melakukan pekerjaan yang } \\
\text { sedang kerjakan }\end{array}$ & 0 & 1 & 30 & 87 & 44 & 162 & 660 & 4.07 & Baik \\
\hline 2 & $\begin{array}{l}\text { Yakin bahwa keterampilan dan } \\
\text { kemampuan sama atau melebihi } \\
\text { daripada teman-teman }\end{array}$ & 0 & 2 & 37 & 86 & 37 & 162 & 644 & 3.98 & Baik \\
\hline 3 & $\begin{array}{l}\text { Menangani pekerjaan yang lebih } \\
\text { menantang daripada pekerjaan } \\
\text { yang sedang dikerjakan }\end{array}$ & 0 & 1 & 26 & 99 & 36 & 162 & 656 & 4.05 & Baik \\
\hline 4 & $\begin{array}{l}\text { Dari sudut profesionalisme, } \\
\text { pekerjaan memuaskan harapan diri } \\
\text { sendiri }\end{array}$ & 0 & 0 & 40 & 83 & 39 & 162 & 647 & 3.99 & Baik \\
\hline 5 & $\begin{array}{l}\text { Memahami tugas pekerjaan yang } \\
\text { dilakukan }\end{array}$ & 0 & 1 & 35 & 89 & 37 & 162 & 648 & 4.00 & Baik \\
\hline 6 & $\begin{array}{l}\text { Setiap kali melakukan pekerjaan } \\
\text { selalu mengutamakan } \\
\text { kuantitas/hasil sesuai dengan } \\
\text { target }\end{array}$ & 0 & 0 & 43 & 85 & 34 & 162 & 639 & 3.94 & Baik \\
\hline 7 & $\begin{array}{l}\text { Dalam menyelesaikan tugas selalu } \\
\text { berusaha tepat waktu }\end{array}$ & 0 & 0 & 18 & 102 & 42 & 162 & 672 & 4.15 & Baik \\
\hline 8 & $\begin{array}{l}\text { Mampu melakukan bekerja secara } \\
\text { efektif dengan memaksimalkan } \\
\text { waktu yang telah tersedia }\end{array}$ & 0 & 1 & 40 & 97 & 24 & 162 & 630 & 3.89 & Baik \\
\hline 9 & $\begin{array}{l}\text { Dalam bekerja, mampu bekerja } \\
\text { secara mandiri }\end{array}$ & 0 & 1 & 35 & 79 & 47 & 162 & 658 & 4.06 & Baik \\
\hline 10 & $\begin{array}{l}\text { Merasa memiliki komitmen dan } \\
\text { tanggung jawab terhadap } \\
\text { pekerjaan }\end{array}$ & 0 & 5 & 30 & 90 & 37 & 162 & 645 & 3.98 & Baik \\
\hline & Rata- Rs & & & & & & & 6499 & 4.01 & Baik \\
\hline
\end{tabular}

Sumber : Hasil Penelitian dan Diolah, 2020

Berdasarkan tabel di atas dapat dilihat bahwa rata-rata tanggapan reponden terhadap variabel self esteem sebesar 4,01 dengan kriteria penilaian baik karena angka tersebut terletak pada interval 3,41 - 4,20. Hal ini menggambarkan bahwa self esteem perawat yang bekerja pada RSUD Hasanuddin Damrah Manna sudah baik.. 
Penilian tertinggi untuk variabel self esteem dapat dilihat pada indikator "Dalam menyelesaikan tugas selalu berusaha tepat waktu" dengan skor sebesar 4,15 pada penilaian baik. Hal ini menggambarkan bahwa perawat yang bekerja pada RSUD Hasanuddin Damrah Manna selalu berusaha untuk bekerja tepat waktu, karena seorang perawat yang bekerja di rumah sakit harus memiliki ketepatan waktu dalam bekerja karena pekerjaan mereka berhubungan dengan keselamatan pasien.

Sedangkan pernyataan terendah untuk variabel self esteem terlihat pada indikator "Mampu melakukan bekerja secara efektif dengan memaksimalkan waktu yang telah tersedia", dengan skor sebesar 3,89 pada kategori baik. Hal ini menjelaskan bahwa perawat mampu menyelesaikan pekerjaan secara efektif dengan waktu yang telah diberikan oleh pihak rumah sakit namun medapat penilaian terendah karena masih terlihat perawat yang suka berbicara dengan rekan kerjanya pada saat bekerja, hal ini akan menurunkan kinerja.

\subsubsection{Tanggapan Responden Terhadap Variabel Kinerja}

Kinerja merupakan hasil kerja secara kualitas dan kuantitas yang dicapai oleh seseorang dalam melaksanakan fungsinya sesuai dengan tanggungjawab yang diberikan kepadanya. Adapun tanggapan responden terhadap variabel kinerja dapat dilihat dari sepuluh indikator penelitian seperti terlihat pada tabel berikut ini: 
Tabel 4.10

Tanggapan Responden Terhadap Variabel Kinerja

\begin{tabular}{|c|c|c|c|c|c|c|c|c|c|c|}
\hline \multirow{2}{*}{ No } & \multirow{2}{*}{ Pernyataan } & \multicolumn{5}{|c|}{ Tanggapan Responden } & \multirow{2}{*}{$\begin{array}{c}\text { Respo } \\
\text { nden }\end{array}$} & \multirow{2}{*}{$\begin{array}{l}\text { Total } \\
\text { Skor }\end{array}$} & \multirow{2}{*}{ Rata-Rata } & \multirow{2}{*}{ Kriteria } \\
\hline & & STS & TS & $\mathrm{N}$ & $\mathrm{S}$ & SS & & & & \\
\hline 1 & $\begin{array}{l}\text { Memiliki keterampilan yang tinggi } \\
\text { dalam bekerja }\end{array}$ & 0 & 0 & 24 & 80 & 58 & 162 & 682 & 4.21 & $\begin{array}{c}\text { Sangat } \\
\text { Baik }\end{array}$ \\
\hline 2 & Selalu teliti dalam bekerja & 0 & 0 & 39 & 82 & 41 & 162 & 650 & 4.01 & Baik \\
\hline 3 & Memiliki target dalam bekerja & 0 & 0 & 47 & 72 & 43 & 162 & 644 & 3.98 & Baik \\
\hline 4 & $\begin{array}{l}\text { Mampu menyeles aikan semua } \\
\text { beban pekerjaan yang diberikan }\end{array}$ & 0 & 0 & 30 & 85 & 47 & 162 & 665 & 4.10 & Baik \\
\hline 5 & $\begin{array}{l}\text { Memiliki pengetahuan yang tinggi } \\
\text { tentang pekerjaan }\end{array}$ & 0 & 0 & 38 & 67 & 57 & 162 & 667 & 4.12 & Baik \\
\hline 6 & $\begin{array}{l}\text { Adanya penempatan karyawan } \\
\text { sesuai dengan latar belakang } \\
\text { pendidikan }\end{array}$ & 0 & 0 & 25 & 68 & 69 & 162 & 692 & 4.27 & $\begin{array}{l}\text { Sangat } \\
\text { Baik }\end{array}$ \\
\hline 7 & $\begin{array}{l}\text { Adanya kerjasama dengan sesama } \\
\text { karyawan }\end{array}$ & 0 & 0 & 32 & 72 & 58 & 162 & 674 & 4.16 & Baik \\
\hline 8 & $\begin{array}{l}\text { Memiliki inovasi yang tinggi dalam } \\
\text { bekerja }\end{array}$ & 0 & 0 & 45 & 79 & 38 & 162 & 641 & 3.96 & Baik \\
\hline 9 & Mampu memecahkan masalah & 0 & 0 & 35 & 79 & 48 & 162 & 661 & 4.08 & Baik \\
\hline 10 & $\begin{array}{l}\text { Adanya inisiatif dalam } \\
\text { memecahkan masalah }\end{array}$ & 0 & 0 & 42 & 90 & 30 & 162 & 636 & 3.93 & Baik \\
\hline \multicolumn{8}{|c|}{ Rata- Rata } & 6612 & 4.08 & Baik \\
\hline
\end{tabular}

Sumber : Hasil Penelitian dan Diolah, 2020

Berdasarkan tabel di atas dapat dilihat bahwa rata-rata tanggapan reponden terhadap variabel kinerja sebesar 4,08 dengan kriteria penilaian baik karena angka tersebut terletak pada interval 3,41 - 4,20. Hal ini menggambarkan bahwa kinerja perawat yang bekerja pada RSUD Hasanuddin Damrah Manna sudah baik.

Penilian tertinggi untuk variabel kinerja dapat dilihat pada indikator “Adanya penempatan karyawan sesuai dengan latar belakang pendidikan” dengan skor sebesar 4,27 pada penilaian sangat baik. Hal ini menggambarkan bahwa penempatan kerja bagi perawat pada RSUD Hasanuddin Damrah Manna sesuai dengan kemampuan dan latar belakang pendidikannya, sehingga perawat mampu melaksanakan semua tugas dan tanggung jawab yang diberikan kepadanya karena 
mereka memahami semua tugas yang diberikan yang sesuai dengan ilmu dan keterampilan yang dimilikinya.

Sedangkan pernyataan terendah untuk variabel kinerja terlihat pada indikator "Adanya inisiatif dalam memecahkan masalah", dengan skor sebesar 3,93 pada kategori baik. Hal ini menjelaskan bahwa perawat memiliki inisiatif dalam penyelesaian masalah yang terjadi pada saat bekerja, perawat tidak hanya bersifat pasif yang hanya bekerja sesuai perintah, tetapi perawat juga memiliki inisiatif untuk mampu menyelesaikan masalah yang terjadi. Mendapatkan penilaian terendah dikarenakan tidak semua perawat memiliki kemampuan untuk memberikan inisiatif dalam bekerja, tetapi meskipun mendapat penilaian terendah indikator ini masih berada pada penilaian baik.

\subsubsection{Analisis Regresi Linier Berganda}

Analisis regresi linier berganda digunakan untuk mengetahui besarnya pengaruh Locus of control, Self Efficacy dan Self Esteem terhadap Kinerja pada RSUD Hasanuddin Damrah Manna. Perhitungan statistik dalam analisis regresi berganda dijelaskan pada tabel berikut ini : 
Tabel 4.11

Hasil Uji Regresi Berganda

\begin{tabular}{|c|c|c|c|c|c|c|}
\hline \multicolumn{7}{|c|}{ Coefficients $^{a}$} \\
\hline \multirow{2}{*}{\multicolumn{2}{|c|}{ Model }} & \multicolumn{2}{|c|}{ Unstandardized Coefficients } & \multirow{2}{*}{$\begin{array}{c}\text { Standardized } \\
\text { Coefficients } \\
\text { Beta }\end{array}$} & \multirow[b]{2}{*}{$\mathrm{t}$} & \multirow[b]{2}{*}{ Sig. } \\
\hline & & B & Std. Error & & & \\
\hline \multirow[t]{4}{*}{1} & (Constant) & 10.422 & 3.568 & & 2.921 & .004 \\
\hline & Locus of control & .172 & .061 & .189 & 2.796 & .006 \\
\hline & Self Efficacy & .257 & .064 & .287 & 3.993 & .000 \\
\hline & Selt Esteem & .335 & .082 & .300 & 4.080 & .000 \\
\hline
\end{tabular}

a. Dependent Variable: Kinerja

Sumber: Penelitian dan diolah, 2020

Dari hasil perhitungan regresi linear berganda dengan menggunakan program SPSS 21.00 maka dapat diperoleh perseamaan regresi linier berganda sebagai berikut :

$$
\mathrm{Y}=10,422+0,172 \mathrm{X} 1+0,257 \mathrm{X} 2+0,335 \mathrm{X} 3
$$

Persamaan regresi tersebut dapat dijelaskan sebagai berikut :

1. Nilai konstanta 10,422 mempunyai arti bahwa apabila variabel Locus of control (X1), Self Efficacy (X2) dan Self Esteem (X3) sama dengan nol maka variabel Kinerja (Y) akan tetap sebesar 10,422

2. Pengaruh Locus of control (X1) terhadap Kinerja (Y)

Nilai koefesien regresi variabel X1 (Locus of control) adalah sebesar 0,172, artinya apabila X1 (Locus of control) mengalami kenaikan sebesar satu-satuan maka Y (Kinerja ) juga akan mengalami kenaikan sebesar 0,172, dengan asumsi variable X2 (Self Efficacy) dan X3 (Self Esteem) tetap.

3. Pengaruh Self Efficacy (X2) terhadap Kinerja (Y)

Nilai koefesien regresi variabel X2 (Self Efficacy) adalah sebesar 0,257, artinya 
apabila X2 (Self Efficacy) mengalami kenaikan sebesar satu-satuan maka Y (Kinerja) juga akan mengalami kenaikan sebesar 0,257, dengan asumsi variable X1 (Locus of control) dan X3 (Self Esteem) tetap.

4. Pengaruh Self Esteem (X3) terhadap Kinerja (Y)

Nilai koefesien regresi variabel X3 (Self Esteem) adalah sebesar 0,335, artinya apabila X3 (Self Esteem) mengalami kenaikan sebesar satu-satuan maka Y (Kinerja ) juga akan mengalami kenaikan sebesar 0,335, dengan asumsi variable X1 (Locus of control) dan X2 (Self Efficacy) tetap.

\subsubsection{Koefisien Determinasi $\left(R^{2}\right)$}

Menurut Sarwono (2013:99) koefisien determinasi menunjukkan besarnya koefesien deterimansi yang berfungsi untuk mengetahui besarnya variablitas variabel tergangung tingkat variabel $(\mathrm{Y})$ yang diterangkan oleh variabel-variabel X. Koefesien Determinasi ini digunakan untuk menghitung besarnya peranan atau pengaruh variabel bebas yaitu X1 (Locus of control), X2 (Self Efficacy) dan X3 (Self Esteem ) terhadap variabel terikatnya yaitu Kinerja (Y).

Nilai koefisien determinasi ditentukan dengan nilai $R$ square Adapun hasil output SPSS untuk koefesien determinasi seperti pada tabel berikut :

Tabel 4.12

Koefesien Determinasi

Model Summary

\begin{tabular}{|l|r|r|r|r|}
\hline Model & $\mathrm{R}$ & \multicolumn{1}{|c|}{ R Square } & Adjusted R Square & \multicolumn{1}{c|}{$\begin{array}{c}\text { Std. Error of the } \\
\text { Estimate }\end{array}$} \\
\hline 1 & $.569^{\mathrm{a}}$ & .324 & .311 & 2.645 \\
\hline
\end{tabular}

a. Predictors: (Constant), Selt Esteem, Locus of control, Self Efficacy

Sumber: Penelitian dan diolah, 2020 
Berdasarkan pendapat Sarjono (2013:99), untuk pengukuran koefesien determinasi digunakan nilai $R$ square. Dari hasil perhitungan dengan menggunakan SPSS dapat diketahui nilai koefesien determinasi dari $R$ square yaitu sebesar 0324 . Hal ini berarti bahwa X1 (Locus of control), X2 (Self Efficacy) dan X3 (Self Esteem) berpengaruh terhadap Kinerja (Y) sebesar 32,4 \% sedangkan sisanya $(100-32,4 \%=67,6 \%$ dipengaruhi oleh faktor-faktor penyebab lainnya yang tidak diteliti dalam penelitian ini.

\subsubsection{Uji t}

Hasil pengujian hipotesis uji t dengan menggunakan SPSS 21.00 adalah sebagai berikut :

Tabel 4.13

Hasil Uji T

Coefficients $^{\mathrm{a}}$

\begin{tabular}{|c|c|c|c|c|c|c|}
\hline \multirow[b]{2}{*}{ Mode } & & \multicolumn{2}{|c|}{ Unstandardized Coefficients } & \multirow{2}{*}{$\begin{array}{c}\text { Standardized } \\
\text { Coefficients } \\
\text { Beta } \\
\end{array}$} & \multirow[b]{2}{*}{$t$} & \multirow[b]{2}{*}{ Sig. } \\
\hline & & $\mathrm{B}$ & Std. Error & & & \\
\hline \multirow[t]{4}{*}{1} & (Constant) & 10.422 & 3.568 & & 2.921 & .004 \\
\hline & Locus of control & .172 & .061 & .189 & 2.796 & .006 \\
\hline & Self Efficacy & .257 & .064 & .287 & 3.993 & .000 \\
\hline & Selt Esteem & .335 & .082 & .300 & 4.080 & .000 \\
\hline
\end{tabular}

a. Dependent Variable: Kinerja

Sumber: Penelitian dan diolah, 2020

Dari hasil perhitungan di atas maka dapat dijelaskan sebagai berikut:

1. Variabel X1 (Locus of control)

Hasil pengujian untuk variabel X1 (Locus of control) menunjukkan nilai thitung $=2,796$ kemudian dibandingkan dengan dengan nilai tabel dengan level of 
signifikan ditetapkan 95\% dengan perhitungan satu arah dan $\mathrm{dk}=\mathrm{n}-3=162-3=$ 159, diketahui nilai $t_{\text {tabel }}$ sebesar 1,654. Maka $t_{\text {hitung }}$ lebih besar dari $t_{\text {tabel }}(2,796$ $>1,654)$ dengan nilai signifikansi sebesar $0,006<0,05$. Karena $t_{\text {hitung }}>t_{\text {tabel }}$ dan nilai signifikansi lebih kecil dari 0,05, maka H0 ditolak dan Ha diterima. Artinya X1 (Locus of control) memiliki pengaruh yang positif dan signifikan terhadap Kinerja (Y)

2. Variabel X2 (Self Efficacy)

Hasil pengujian untuk variabel X2 (Self Efficacy) menunjukkan nilai thitung $=$ 3,993 kemudian dibandingkan dengan dengan nilai tabel dengan level of signifikan ditetapkan 95\% dengan perhitungan satu arah dan $\mathrm{dk}=\mathrm{n}-3=162-3=$ 159, diketahui nilai tabel sebesar 1,654. Maka thitung lebih besar dari tabel $(3,993>1,654)$ dengan nilai signifikansi sebesar $0,000<0,05$. Karena thitung $>$ $\mathrm{t}_{\text {tabel }}$ dan nilai signifikansi lebih kecil dari 0,05 , maka $\mathrm{HO}$ ditolak dan $\mathrm{Ha}$ diterima. Artinya X2 (Self Efficacy) memiliki pengaruh yang positif dan signifikan terhadap Kinerja (Y).

2. Variabel X3 (Self Esteem )

Hasil pengujian untuk variabel X3 (Self Esteem ) menunjukkan nilai $t_{\text {hitung }}=$ 4,080 kemudian dibandingkan dengan dengan nilai $t_{\text {tabel }}$ dengan level of signifikan ditetapkan 95\% dengan perhitungan satu arah dan $\mathrm{dk}=\mathrm{n}-3=162-$ $3=159$, diketahui nilai $t_{\text {tabel }}$ sebesar 1,654. Maka thitung lebih besar dari tabel $(4,080>1,654)$ dengan nilai signifikansi sebesar $0,000<0,05$. Karena $t_{\text {hitung }}>$ $\mathrm{t}_{\text {tabel }}$ dan nilai signifikansi lebih kecil dari 0,05 , maka $\mathrm{H} 0$ ditolak dan $\mathrm{Ha}$ diterima. Artinya X3 (Self Esteem) memiliki pengaruh yang positif dan signifikan terhadap Kinerja (Y). 


\subsubsection{Uji F}

Dalam penelitian ini pengujian hipotesis dimaksudkan untuk mengukur besarnya pengaruh X1 (Locus of control), X2 (Self Efficacy) dan X3 (Self Esteem) berpengaruh terhadap Kinerja (Y) maka digunakan uji F. berdasarkan hasil pengujian hipotesis Uji Anova atau uji F terlihat pada tabel berikut.

Tabel 4.14

Hasil Uji F

ANOVAa

\begin{tabular}{|ll|r|r|r|r|r|}
\hline \multicolumn{1}{|l|}{ Model } & & Sum of Squares & df & Mean Square & F & Sig. \\
\hline 1 & Regression & 529.253 & 3 & 176.418 & 25.221 & $.000^{\mathrm{b}}$ \\
& Residual & 1105.192 & 158 & 6.995 & & \\
& Total & 1634.444 & 161 & & & \\
\hline
\end{tabular}

a. Dependent Variable: Kinerja

b. Predictors: (Constant), Selt Esteem, Locus of control, Self Efficacy

Sumber: Penelitian dan diolah, 2020

Hasil perhitungan statistik menunjukkan nilai $\mathrm{F}$ hitung $=25,221$ sedangkan $\mathrm{F}_{\text {tabel }}(\mathrm{df} 1=\mathrm{k}-1=3-1=2$, sedangkan $\mathrm{df} 2=\mathrm{n}-\mathrm{k}=162-3=159$, alpha $=5 \%)$ adalah sebesar 3,05, berarti diperoleh $F_{\text {hitung }}>F_{\text {tabel }}(25,221>3,05)$ sejalan dengan signifikansi sebesar $0,000<0,05$. Karena nilai $F_{\text {hitung }}>F_{\text {tabel }}$ dan tingkat signifikansi di bawah 0,05 menunjukkan bahwa secara bersama-sama X1 (Locus of control), X2 (Self Efficacy) dan X3 (Self Esteem ) mempunyai pengaruh yang positif dan signifikan terhadap Kinerja (Y). Maka berdasarkan hasil uji simultan maka H0 ditolak dan Ha diterima, antara Variabel-variabel bebas yaitu X1 (Locus of control), X2 (Self Efficacy), X3 (Self Esteem), mempunyai pengaruh yang signifikan secara bersama-sama terhadap Kinerja (Y). 


\subsection{Pembahasan}

\subsubsection{Pengaruh Locus Of Control Terhadap Kinerja}

Berdasarkan hasil penelitian dapat dilihat adanya pengaruh yang signifikan antara locus of control terhadap kinerja karena nilai signfikan sebesar 0,006 lebih kecil dari 0,05. Artinya semakin meningkat locus of control pada perawat RSUD Hasanuddin Damrah Manna maka kinerja juga akan meningkat. Hal ini menggambarkan dengan adanya pengendalian diri dari para perawat maka kinerja karyawan akan meningkat.

Locus of control yang dimiliki oleh perawat mampu meningkatkan kinerja perawat dalam bekerja karena perawat selalu bekerja keras melayani pasien tanpa adanya paksaan, perawat mampu memecahkan masalah yang dihadapinya dalam bekerja, perawat yakin bahwa semua keberhasilan yang mereka capai dalam kehidupannya merupakan usaha dia sendiri. Dalam bekerja perawat memiliki keyakinan terhadap kemampuan dirinya sehingga membuat perawat memiliki kepercayaan dalam mengobati pasien.

Hasil penelitian ini sesuai dengan pendapat Robbins dan Judge (2014:45) mendefinisikan Locus of control sebagai tingkat dimana individu yakin bahwa mereka adalah penentu nasib mereka sendiri. Internal adalah sikap dari individu yang memiliki suatu keyakinan bahwa dirinya merupakan pemegang kendali atas apa-apa pun yang terjadi pada dirinya sendiri, sedangkan eksternal adalah seseoarang memiliki keyakinan bahwa yang terjadi pada diri mereka dikendalikan oleh kekuatan luar seperti keberuntungan dan kesempatan.

Hasil penelitian mendukung penelitian terdahulu yang dilkukan oleh Ari 
Sinar Deany (2016) yang menemukan adanya pengaruh yang signifikan antara locus of control terhadap kinerja. Penelitian ini juga sama dengan penelitian Rano Purnomo (2010) dengan hasil penelitian adanya pengaruh locus of control terhadap kinerja.

\subsubsection{Pengaruh Self-Efficancy Terhadap Kinerja}

Hasil penelitian menunjukkan bahwa variabel self efficacy berpengaruh signifikan terhadap kinerja perawat karena nilai signifikan sebesar 0,000 lebih kecil dari 0,05 . Artinya semakin meningkat self efficacy maka kinerja perawat pada RSUD Hasanuddin Damrah Manna juga akan meningkat. Hal ini menggambarkan bahwa dengan adanya pemikiran bahwa dirinya memiliki manfaat bagi orang lain, memiliki kualitas dalam bekerja, mampu melakukan pekerjaan dengan baik maka seorang perawat akan bekerja dengan baik.

Hal ini sesuai dengan penelitian Erez dan Judge (2001) yang menemukan adanya pengaruh self efficacy terhadap kinerja. Self efficacy merupakan penilaian individu terhadap kemampuan atau kompetensinya untuk melakukan suatu tugas, mencapai suatu tujuan dan menghasilkan sesuatu. Self efficacy dapat dikatakan sebagai faktor personal yang membedakan setiap individu, dimana perubahan self efficacy dapat menyebabkan perubahan perilaku terutama dalam penyelesaian tugas dan tujuan. Terlihat bahwa perubahan self efficacy besar pengaruhnya terhadap kinerja perawat secara langsung

Menurut Enggo (2007) hasil penelitiaannya menunjukan bahwa self efficacy berpengaruh signifikan terhadap kinerja individual. Roharjo (2010) hasil 
penelitiannya menunjukan bahwa self efficacy berpenngaruh signifikan terhadap kinerja individual auditor dalam menjalankan profesi. Prasetya et al (2013) hasil penelitiannya menunjukan self efficacy berpengaruh positif yang signifikan terhadap kinerja individual karyawan, semakin tinggi tingkat self efficacy yang dimiliki karyawan didalam bekerja akan mendorong meningkatnya kinerja individual dalam bekerja.

Hasil penelitian ini sejalan dengan penelitian terdahulu yang dilakukan oleh Stevani Sabayan (2017) yang menemukan adanya pengaru yang signifikan antara self efficacy terhadap kinerja. Namun tidak mendukung penelitian yang dilakukan oleh Rezi Frinelya (2016) dengan hasil penelitian tidak adanya pengaruh dari serlf efficacy terhadap kinerja.

\subsubsection{Pengaruh Self Esteem Terhadap Kinerja}

Berdasarkan hasil penelitian menunjukkan bahwa self esteem berpengaruh signifikan terhadap kinerja perawat karena nilai signifikan sebesar 0,00 lebih kecil dari 0,05. Artinya semakin meningkat self esteem maka kinerja perawat pada RSUD Hasanuddin Damrah Manna juga akan meningkat. Hal ini menjelaskan bahwa dengan adanya self esteem pada perawat maka perawat memiliki kekuatan dalam bekerja seperti mampu melakukan pekerjaan yang sedang dikerjakan, yakin bahwa keterampilan dan kemampuan yang sama dengan orang lain, menangani pekerjaan yang lebih menantang dan selalu professional dalam bekerja. Perawat akan memberikan pelayanan maksimal terhadap pasien dengan cara selalu tepat waktu dalam melayani pasien, memberikan obat pasien tepat waktu, memberikan 
perawatan sesuai dengan anjuran dokter dan dalam bekerja mampu bekerja secara mandiri.

Hal ini sesuai dengan penelitian yang dilakukan oleh Brockner (1998). Self esteem diartikan sebagai suatu keyakinan nilai diri sendiri berdasarkan evaluasi diri secara keseluruhan. Membangun self esteem membutuhkan waktu dan kesadaran, namun akan membangkitkan rasa percaya diri, penghargaan diri, rasa bahwa kehadirannya diperlukan dalam dunia ini. Seseorang dengan self esteem yang tinggi secara langsung mempengaruhi kinerjanya karena perasaan self esteem pada kenyataannya dipengaruhi oleh keadaan diri dan bagaimana lingkungan memperlakukan mereka. Mereka perlu diberikan penghargaan atas prestasi yang telah mereka perbuat, dipenuhi semua kebutuhannya, barulah kepuasan kerja tercapai dan kinerja pun meningkat.

Hasil penelitian mendukung penelitian terdahulu yang dilakukan oleh Ari Sinar Deany (2016) dan Stevani Sebayan (2017) yang menemukan bahwa adanya pengaruh dari self esteem terhadap kinerja. Namun tidak mendukung penelitian yang dilakukan oleh Rezi Frinelya (2016) dengan hasil penelitian tidak adanya pengaruh dari serlf esteem terhadap kinerja.

\subsubsection{Pengaruh Locus Of Control, Self Efficacy dan Self Esteem Terhadap Kinerja}

Berdasarkan hasil pengujian secara simultan atau bersama-sama maka dapat dibuktikan adanya pengaruh yang signifikan antara locus of control, self efficacy dan self esteem terhadap kinerja Perawat pada RSUD Hasanuddin Damra Manna 
karena nilai signifikan lebih kecil dari 0,05. Hal ini menggambarkan dengan adanya locus of control yang dimiliki oleh perawat serta self efficacy dan self esteem dapat meningkat tingkat kepercayaan perawat terhadap dirinya sendiri bahwa mereka memiliki kemampuan dalam melaksanakan semua pekerjaannya dengan kemampuan yang mereka miliki.

Hasil penelitian ini menggambarkan bahwa untuk meningkatkan kinerja maka seorang harus mampu mengendalikan dirinya, sesuai dengan pendapat Menezes, (2008) bahwa Locus of control ini dapat digunakan pegawai untuk mengendalikan perilakunya dalam bekerja. Hal lain juga disampaikan oleh Chaturvedi dan Chander (2010) emotional stability sering kali menunjukkan tingkat kedewasaan kepribadian (maturity personality) seseorang. Emosi yang tidak stabil menunjukkan bahwa orang tersebut memiliki kepribadian yang tidak dewasa (immature personality). Individu yang kepribadiannya tidak dewasa ditandai dengan ketidakmampuan individu mengontrol diri, tidak mampu bersikap objektif terhadap suatu masalah tugas sehingga tidak mampu membedakan antara masalah pribadi dan masalah tugas pekerjaan, cenderung emosional, menyimpan dendam dan mudah tersinggung. Sehingga dapat dijelaskan bahwa emosi merupakan salah satu faktor yang mempengaruhi tingkah laku manusia.

Hasil penelitian ini mendukung hasil penelitian yang dilakukan oleh Nisrin Husna1 (2014) dengan hasil penelitian bahwa locus of control, self efficacy dan self esteem memiliki pengaruh secara bersama-sama terhadap kinerja. 


\section{BAB V}

PENUTUP

\subsection{Kesimpulan}

Berdasarkan hasil penelitian dan pembahasan yang telah dijabarkan sebelumnya, maka dapat disimpulkan sebagai berikut :

1. Locus of control memiliki pengaruh positif dan signifikan terhadap kinerja perawat pada RSUD Hasanuddin Damrah Manna.

2. Self efficacy memiliki pengaruh positif dan signifikan terhadap kinerja perawat pada RSUD Hasanuddin Damrah Manna.

3. Self esteem memiliki pengaruh positif dan signifikan terhadap kinerja perawat pada RSUD Hasanuddin Damrah Manna

4. Locus of control, self efficacy dan self esteem memiliki pengaruh positif dan signifikan secara bersama-sama terhadap kinerja perawat pada RSUD Hasanuddin Manna.

\section{AFTAR PUSTAKA}

Anjani, R. (2019). Tata Kelola Adminitrasi Keuangan, Dan Pembangunan Desa Tepi Laut Kabupaten Bengkulu Utara. Jurnal Pengabdian Masyarakat Bumi Raflesia, 2 (2).

Andriani, C., \& Onsardi, O. (2020). Pengaruh Kompensasi, Pelatihan Kerja Dan Kepuasan Kerja Terhadap Kinerja Karyawan Marketing. (Jems) Jurnal Entrepreneur Dan Manajemen Sains, 1(2).

Asmawi, M. (2017). The effect of compensation, empowerment, and job satisfaction on employee loyalty. International Journal of Scientific Research and Management, 5(12), 7590-7599. 
Ari Sinar Deany, 2016. Pengaruh Self Esteem, Self Efficacy, Locus Of Control, Dan Emotional Stability Pada Kinerja Pengelola Anggaran Belanja Universitas Udayana. E-Jurnal Ekonomi dan Bisnis Universitas Udayana 5.11 (2016)

Bandura, A, 2007, Self efficacy Mechanism in Psychological and HealthPromoting Behavior, Prentice Hall, New Jersey.

Beane, J.A. \& Lipka, R.P. 2009. Self Concept. Self Esteem and The Curiculum. Teacher College Press. York.

Boeree, G. C. 2006. Personality Theories. Jogjakarta: Prisma Sophie

Brownell, Peter, 2008, The Role of Accounting Data in Performance Evaluation, Budgetary Participation, and Organizational Effectiveness, Journal of Accounting Research, Vol 20, pp 12-27

Coopersmith, S. 2014. The Antecedents Of Self-Esteem. San Francisco : Freeman and Company

Dymastara, E. S., \& Onsardi, O. (2020). Analisis Reward Dan Punishment Terhadap Kinerja Karyawan Pt. Sandabi Indah Lestari Bengkulu Utara. (Jems) Jurnal Entrepreneur Dan Manajemen Sains, 1(2).

Frey, D dan Carlock, C.J. 2007. Enhancing Self Esteem. Ohio: Accelerated Development

Gardner, D. G. Dyne L, 2013. The Effect of Pay on Organization Based Selft Esteem and Performance: Afield Study. Journal of Occupation and Organization Psholigy.

Ghozali, Imam. 2012. Aplikasi Analisis Multivariate dengan Program IBM SPSS. Yogyakarta: Universitas Diponegoro

Harbani. 2013. Teori Administrasi Publik, Alfabeta, Bandung.

Kreitner and Kinicki. 2016. Perilaku Organisasi. Edisi 5. Jakarta : Salemba Empat

Lauster, Peter. 2012. Tes Kepribadian (Alih Bahasa: D.H Gulo). Edisi Bahasa Indonesia. Cetakan Ketigabelas. Jakarta: Bumi Aksara.

Mangkunegara, 2008. Manajemen Sumber Daya manusia Perusahaan. Bandung : Rosda

Onsardi, O. (2018). Loyalitas Karyawan pada Universitas Swasta di Kota Bengkulu. COSTING: Journal of Economic, Bussines and Accounting, 2(1), 1-13. 
Onsardi, O. (2019). Pengaruh Kompensasi Dan Pemberdayaan, Terhadap Loyalitas Karyawan Dengan Variabel Intervening Kepuasan Kerja (No. jsypg). Center for Open Science.

Onsardi, O. (2020). Manajemen Sumber Daya Manusia (No. yq85t). Center for Open Science.

Prawirosentono Suyadi, 2013. Manajemen Sumber Daya Manusia; Kebijakan Kinerja Karyawan; Kiat Membangun organisasi Kompetitif era Perdagangan Bebas Dunia. BPFE; Jogyakarta

Ratno Purnomo, 2010. Pengaruh Kepribadian, Self-Efficacy, Dan Locus Of Control Terhadap Persepsi Kinerja Usaha Skala Kecil Dan Menengah. Jurnal Bisnis dan Ekonomi (JBE), September 2010, Hal. 144 - 160

Robbins, S.P dan Judge, T.A., 2014, Perilaku Organisasi (alih bahasa Drs. Benjamin Molan), Edisi Bahasa Indonesia, Klaten: PT. Intan Sejati.

Rosenberg, D. M. and V. H. Resh. 2011. Fresh Water Biomonitoring and Benthic Macroinvertebrates. Chapman and Hall. New York, London

Rotter, J.B. 2014. Genaralized Expectancies for Internal Versus External control of Reinforcement. Pshycologycal Monographs, Vol 80, No 69.

Sanjiwani, Putrid an Wisadha, Suparta. 2016. Pengaruh Locus Of Control, Gaya Kepemimpinan, dan Komitmen Organisasi Pada Kantor Akuntan Publik. E-Jurnal Akuntansi Universitas Udayana. ISSN: 2302-8556.

Siagian Sondang. 2009, Manajemen Sumber Daya Manusia, Jakarta: PT.Bumi Aksara

Stevani, Sebayan. 2017. Pengaruh Self Esteem Dan Self Efficacy Terhadap Kinerja Karyawan Studi Kasus Di PT. Finnet Indonesia. e- Proceeding of Management. ISSN: 2355-9357. Vol. 4, No. 1, April 2017

Sugiyono. 2013. Metode Penelitian Pendidikan Pendekatan Kuantitatif, Kualitatif, dan $R \& D$. Bandung: Alfabeta

Tupadela, J., \& Onsardi, O. (2020). Pengaruh Pengembangan Karir Dan Promosi Jabatan Terhadap Semangat Kerja Karyawan Perusahaan Daerah Air Minum Kota Bengkulu. (Jems) Jurnal Entrepreneur Dan Manajemen Sains, 1(2).

Umar, Husein, 2011, Riset Pemasaran dan Perilaku Konsumen, Penerbit PT. Gramedia Pustaka Utama

Yunianti Elis, dkk. 2016. Pengaruh Model Pembelajaran Dan Self-Efficacy Terhadap Hasil Belajar Matematika Siswa Sma Negeri 1 Parigi: EJurnalMitra Sains. Vol 4. No.1 
